\title{
ValpoScholar
}

Valparaiso University Law Review

Volume 43

Number 4 Symposium: Torture Justifiable?

pp. $1535-1576$

Symposium: Torture Justifiable?

\section{The Absolute Prohibition of Torture and Necessary and Appropriate Sanctions}

Jordan J. Paust

Follow this and additional works at: https://scholar.valpo.edu/vulr

Part of the Law Commons

\section{Recommended Citation}

Jordan J. Paust, The Absolute Prohibition of Torture and Necessary and Appropriate Sanctions, 43 Val. U. L. Rev. 1535 (2009).

Available at: https://scholar.valpo.edu/vulr/vol43/iss4/1

This Symposium is brought to you for free and open access by the Valparaiso University Law School at ValpoScholar. It has been accepted for inclusion in Valparaiso University Law Review by an authorized administrator of ValpoScholar. For more information, please contact a ValpoScholar staff member at scholar@valpo.edu. 


\title{
THE ABSOLUTE PROHIBITION OF TORTURE AND NECESSARY AND APPROPRIATE SANCTIONS
}

\author{
Jordan J. Paust ${ }^{*}$

\section{THE PEREMPTORY PROHIBITION}

Torture is a form of treatment of human beings that is absolutely prohibited under various forms of customary and treaty-based international law in all social contexts. ${ }^{1}$ Other forms of treatment that are absolutely prohibited and often proscribed in the same international instruments that outlaw torture include prohibitions of cruel, inhumane, and degrading treatment. ${ }^{2}$ Additionally, each form of ill-treatment constitutes a violation of peremptory rights and prohibitions $j u s \operatorname{cogens}^{3}$ that trumps any inconsistent portion of an international agreement and more ordinary forms of customary international law. ${ }^{4}$ These forms of illtreatment can never constitute lawful public acts by any state or public official. Furthermore, as customary rights and prohibitions jus cogens, each right and prohibition applies universally and without any attempted limitations in reservations with respect to a particular treaty. ${ }^{5}$

\footnotetext{
* Mike \& Teresa Baker Law Center Professor, University of Houston. Thanks to Dan Baker of our library staff for useful research.

1 See, e.g., Jordan J. Paust, Executive Plans and Authorizations to Violate International Law Concerning Treatment and Interrogation of Detainees, 43 COLUM. J. TRANSNAT'L L. 811, 816-18, 820-22, 846 (2005) [hereinafter Paust, Executive Plans]; Jordan J. Paust, Above the Law: Unlawful Executive Authorizations Regarding Detainee Treatment, Secret Renditions, Domestic Spying, and Claims to Unchecked Executive Power, 2007 UTAH L. REV. 345, 360-64, 366 (2007) [hereinafter Paust, Above the Law]; Committee Against Torture, Gen. Comm. No. 2, Implementation of Article 2 by States parties, paras. 1, 5, U.N. Doc. CAT/C/GC/2 (24 Jan. 2008) [hereinafter CAT Comm. Gen. Comm.]; text infra note 67. The articles have been revised in JORDAN J. PAUST, BEYOND THE LAW: THE BUSH ADMINISTRATION'S UNLAWFUL RESPONSES IN THE "WAR" ON TERROR (2007) [hereinafter PAUST, BEYOND THE LAW]. Since there is no necessity or other exception, as a matter of law, there is no necessity defense.

2 See, e.g., Paust, Executive Plans, supra note 1, at 816-22, 835, 845-46. See PAUST, BEYOND THE LAW, supra note 1 , at $30-31$. This is why it is inadequate for a government to state merely that it does not allow torture. Such a statement was part of a repeated ploy of the Bush Administration despite the fact that any lawyer in the Administration who was not professionally irresponsible would have known that inhumane treatment of any person under any circumstance is unlawful. Id.

3 See, e.g., id. at 821 \& nn.39-40; RESTATEMENT OF THE FOREIGN RELATIONS LAW OF THE UNITED STATES § 702(d), cmnt. n (3d ed. 1987).

With respect to the nature of jus cogens norms, see, e.g., JORDAN J. PAUST, JON M. VAN DYKE, LiNDA A. MALONE, INTERNATIONAL LAW AND LiTIGATION IN THE U.S. 61-63 (2d ed. 2005); CAT Comm. Gen. Comm., supra note 1, para. 1.

5 See, e.g., Paust, Executive Plans, supra note 1, at 822-23.
}

1535 
As customary human rights prohibitions, they also apply universally and in all social contexts as part of the legal obligation of all members of the United Nations under the United Nations Charter to ensure "universal respect for, and observance of, human rights...."6

In December 2007, the United Nations General Assembly reaffirmed nearly unanimous and consistent patterns of legal expectation or opinio juris,7 stating that "no one shall be subjected to torture or to other cruel, inhuman or degrading treatment or punishment $[;] " 8$ that freedom from such unlawful treatment "is a non-derogable right that must be protected under all circumstances, including in times of international or internal armed conflict or disturbance[;]"9 and, that "a number of international, regional and domestic courts ... have recognized that the prohibition of torture is a peremptory norm of international law and have held that the prohibition of cruel, inhuman or degrading treatment or punishment is customary international law[.]"10 Stressing the absolute prohibition of torture and other outlawed forms of ill-treatment, the General Assembly condemned "all forms" of such "treatment or

\footnotetext{
6 See, e.g., U.N. Charter, arts. 55(c), 56; Declaration on Principles of International Law Concerning Friendly Relations and Co-Operation Among States in Accordance With the Charter of the United Nations, U.N. G.A. Res. 2625 (Oct. 24, 1970), 25 U.N. GAOR, Supp. No. 28, at 121, U.N. Doc. A/8028 (1971) ("Every State has the duty to promote through joint and separate action universal respect for and observance of human rights and fundamental freedoms in accordance with the Charter."); Filartiga v. Pena-Irala, 630 F.2d 876, 882 (2d Cir. 1980), observing with respect to Articles 55(c) and 56 of the Charter that the guaranties include, at a bare minimum, the right to be free from torture. This prohibition has become part of customary international law, as evidenced and defined by the Universal Declaration of Human Rights, General Assembly Resolution 217 (III)(A) (Dec. 10, 1948) which states, in the plainest of terms, 'no one shall be subjected to torture.' The General Assembly has declared that the Charter precepts embodied in this Universal Declaration 'constitute basic principles of international law.'Id. (footnote omitted) (quoting G.A. Res. 2625 (XXV) (Oct. 24, 1970) [the 1970 Declaration on Principles of International Law]).

Id.

7 Concerning the nature of opinio juris as an element of customary international law, see, e.g., PAUST, VAN DYKE, MALONE, supra note 4, at 4, 29-30, 42-43, 46-48, 93-94, 102-03, 105.

8 Torture and Other Cruel, Inhuman or Degrading Treatment or Punishment, U.N. G.A. Res. 62/148, prmbl. (18 Dec. 2007), U.N. Doc. A/RES/62/148 (4 Mar. 2008). A 2008 resolution with the same title reaffirmed this and the three points that appear here in the text at notes 9-11. See U.N. G.A. Res. 63/166, prmbl. (18 Dec. 2008), U.N. Doc. A/RES/63/166 (19 Feb. 2009). Similar prior resolutions with the same name reaffirmed many of the same points. See, e.g., U.N. G.A. Res. 61/153, pmbl. (19 Dec. 2006), U.N. Doc. A/RES/61/153 (14 Feb. 2007); U.N. G.A. Res. 60/148 (16 Dec. 2005), U.N. Doc. A/RES/60/148 (21 Feb. 2006).

9 U.N. G.A. Res. 62/148, supra note 8, pmbl.

$10 \quad$ Id. pmbl.
} 
punishment, including ... intimidation," and reiterated the fundamental expectation of the international community that such forms of illtreatment "are and shall remain prohibited at any time and in any place whatsoever and can thus never be justified[.]"11 One year earlier, the General Assembly had reaffirmed that "States are under the obligation to protect all human rights and fundamental freedoms of all persons[]"12 and that "States must ensure that any measure taken to combat terrorism complies with their obligations under international law, in particular[,] international human rights, refugee and humanitarian law[.]"13

\section{CRIMES OF TORTURE AND SANCTION DUTIES}

With respect to the obligation of every state to enforce such rights and prohibitions and the criminal nature of such forms of ill-treatment, the General Assembly has condemned "any action or attempt... to legalize, authorize or acquiesce in torture and other cruel, inhuman or degrading treatment ... under any circumstances, including on grounds of national security or through judicial decisions[.]"14 The General Assembly stressed that allegations that such forms of ill-treatment have occurred "must be promptly and impartially examined... [and with respect to nonimmunity and the duty to prosecute,] those who encourage, order, tolerate or perpetrate acts of torture must be held responsible, brought to justice ... and severely punished, including the officials in charge of the place of detention[.]"15 The General Assembly

$11 \quad$ Id. 11.

12 Protection of Human Rights and Fundamental Freedoms While Countering Terrorism, U.N. G.A. Res. 61/171, pmbl. (19 Dec. 2006), U.N. Doc. A/RES/61/171 (1 Mar. 2007). The same language appeared in a 2008 resolution by the same title. U.N. G.A. Res. 63/185, prmbl. (18 Dec. 2008), U.N. Doc. A/RES/63/185 (3 Mar. 2009).

13 Id. T 1. The same language appears in a 2008 resolution. See U.N. G.A. Res. 63/185, supra note 12, prmbl. The 2006 resolution used the same language that appeared in a 2004 resolution with the same title. G.A. Res. 59/191, para. 1 (Dec. 20, 2004), U.N. Doc. A/RES/59/191 (Mar. 10, 2005). See also Human Rights and Terrorism, U.N. G.A. Res. 59/195, pmbl. (Dec. 20, 2004) (which states, in part, "Reaffirming that all measures to counter terrorism must be in strict conformity with international law, including international human rights standards and obligations[]") U.N. Doc. A/RES/59/195 (Mar. 22, 2005).

14 U.N. G.A. Res. 63/166, supra note 8, at para. 5; G.A. Res. 62/148, supra note 8, 94.

15 U.N. G.A. Res. 63/166, supra note 8, at para. 6. See also id. para. 17 ("[c]alls upon State parties to the ... [CAT] to fulfil their obligation to submit for prosecution or extradite those alleged to have committed acts of torture"); U.N. G.A. Res. 62/148, supra note 8, at para. 5. See also Basic Principles and Guidelines on the Right to a Remedy and Reparation for Victims of Gross Violations of International Human Rights Law and Serious Violations of International Humanitarian Law, G.A. Res. 60/147, Annex, part III, ๆ 4, U.N. Doc. A/RES/60/147/Annex (Mar. 21, 2006), stating the following:

In cases of gross violations of international human rights law and 
Valparaiso University Law Review, Vol. 43, No. 4 [2009], Art. 1

also emphasized that during armed conflict "acts of torture... are serious violations of international humanitarian law and...constitute war crimes[]" and that perpetrators "must be prosecuted and punished[.]" Moreover, these acts can also constitute "crimes against humanity"16 - a point evident in the customary post-World War II charters and laws created for prosecution of customary crimes against humanity in the international criminal tribunals at Nuremberg and Tokyo and in numerous fora that operated in Europe under Control Council Law No. 10, which crimes expressly included torture and "other inhumane acts[.]"17

The General Assembly also took note of the fact that "prolonged incommunicado detention or detention in secret places can facilitate the perpetration of torture and other cruel, inhuman or degrading treatment or punishment and can in itself constitute a form of such treatment[.]"18 In 2006, in response to unlawful conduct authorized by President Bush and others in his administration, ${ }^{19}$ the Committee Against Torture, which operates under the auspices of the Convention Against Torture and Other Cruel, Inhuman or Degrading Treatment or Punishment

serious violations of international humanitarian law constituting crimes under international law, States have the duty to investigate and, if there is sufficient evidence, the duty to submit to prosecution the person allegedly responsible for the violations and, if found guilty, the duty to punish her or him.

Id. U.N. Doc. A/RES/60/147 (21 Mar. 2006); Office High Comm'n H.R. [OHCHR] Torture and Other Cruel, Inhuman or Degrading Treatment or Punishment, Res. 32, U.N. Doc. E/CN.4/RES/1999/32 (26 Apr. 1999); Office High Comm'n H.R. [OHCHR], Res. 1999/1 (6 Apr. 1999), quoted in Martin Scheinin, Yuji Iwasawa, Andrew C. Byrnes, \& Menno T. Kamminga, Final Report on the Exercise of Universal Jurisdiction in Respect of Gross Human Rights Offenses 7, INTERNATIONAL LAW ASSOCIATION CONFERENCE (London 2000); infra notes $26-28,31-32$.

16 G.A. Res. 62/148, supra note $8, \uparrow 6$. Prosecution of torture as a crime against humanity has occurred in the International Criminal Tribunal for Former Yugoslavia (ICTY). See, e.g., The Prosecutor v. Kunarac, Kovac, and Vukovic, ICTY-96-23/1-T (Trial Chamber, 22 Feb. 2001).

17 See, e.g., U.N. HCR, Charter of the International Military Tribunal at Nuremberg, Annex to the London Agreement, art. 6(c) (Aug. 8, 1945) ("other inhumane acts committed against any civilian population[] ...."); Charter for the International Military Tribunal for the Far East (Tokyo Charter), art. 5(c), as amended by General Orders No. 20 (Apr. 26, 1946) ("other inhumane acts committed ... before or during the war[]"); Allied Control Council Law No. 10, art. II(1)(c), (Dec. 20, 1945) ("torture, rape, or other inhumane acts committed against any civilian population[] ...."); Control Council for Germany, OfFICIAL GAZETTE 50 (Jan. 31, 1946).

18 U.N. G.A. Res. 63/166, supra note 8, at para. 20; G.A. Res. 62/148, supra note 8, 15. See also G.A. Res. 61/153, supra note 8, 12.

19 See, e.g., Paust, Executive Plans, supra note 1, at 812, 824-51; Paust, Above the Law, supra note 1 , at 345-59. 
$(\mathrm{CAT}),{ }^{20}$ recognized that "secret detention... constitutes, per se, a violation of the Convention[]" and that "enforced disappearance [a previously widely recognized crime against humanity under customary international law $]^{21}$... constitutes, per se, a violation of the Convention."22 The Committee Against Torture also declared that "detaining persons indefinitely without charge, constitutes per se a violation of the Convention[.]" 23

Also in 2006, the United Nations Security Council reaffirmed "its condemnation in the strongest terms of all acts of violence or abuses committed against civilians in situations of armed conflict... in

20 Convention Against Torture and Other Cruel, Inhuman or Degrading Treatment or Punishment, Dec. 10, 1984, 1465 U.N.T.S. 85. [hereinafter CAT].

${ }^{21}$ With respect to the crime against humanity known as forced disappearance and involving a refusal to disclose either the name or whereabouts of a detainee, see, e.g., Rome Statute of the International Criminal Court, art. 7(1)(i), (2)(i) (forced disappearance is a crime against humanity); Rome Statute of the International Criminal Court, July 1, 2002, 2187 U.N.T.S. 90 [hereinafter Rome Statute of the ICC]; International Convention for the Protection of All Persons from Enforced Disappearance, pmbl., adopted by G.A. Res. 61/177, U.N. Doc. A/61/177 (Dec. 20, 2006); 22 U.S.C. § 2304(d) ("causing the disappearance of persons" is among "flagrant" and "gross violations of internationally recognized human rights"); S. REP. NO. 102-249, at 9 (1991), quoted in Xuncax, 886 F. Supp. at 172; The Prosecutor v. Kupreskic, ICTY-95-16-T (Trial Chamber, Judgment, 14 Jan. 2000); In re Marcos, Human Rights Litigation, 25 F.3d 1467, 1475 (9th Cir. 1994); Bowoto v. Chevron Corp., No. C99-02506 SI, 2007 WL 2349336 at *29 (N.D. Cal. Aug. 14, 2007) ("there is sufficient circumstantial evidence of . . f forced disappearance [in Nigeria] to support tort claims"); Tachiona v. Mugabe, 234 F. Supp. 2d 401, 416, 426 (S.D.N.Y. 2002); Xuncax v. Gramajo, 886 F. Supp. 162, 184-85 (D. Mass. 1995); Forti v. Suarez-Mason, 694 F. Supp. 707, 710-12 (N.D. Cal. 1988); 22 U.S.C. § 2151n(a) (2000); Inter-American Convention on the Forced Disappearance of Persons, art. II, June 9, 1994, reprinted in 33 I.L.M. 1529, 1529 (1994); Council of Europe Parliamentary Assembly, Res. 1433, Lawfulness of Detentions by the United States in Guantanamo Bay, paras. 7(vi), 8(vii)-(viii) (26 Apr. 2005); JEAN-MARIE HENCKAERTS \& LOUISE DOSWALD-BECK, CUSTOMARY INTERNATIONAL HUMANITARIAN LAW: RULES 340-43, 421, 439 (ICRC 2005); Jose E. Alvarez, Torturing the Law, 37 CASE W. RES. J. INT'L L. 175, 199, 210-11, 213 (2006); M. Cherif Bassiouni, The Institutionalization of Torture Under the Bush Administration, 37 CASE W. RES. J. INT'L L. 389, 411-13 (2006); Maureen R. Berman, Roger C. Clark, State Terrorism: Disappearances, 13 RUTGERS L.J. 531, 531 (1982); Jordan J. Paust, Post-9/11 Overreaction and Fallacies Regarding War and Defense, Guantanamo, the Status of Persons, Treatment, Judicial Review of Detention, and Due Process in Military Commissions, 70 Notre DAME L. Rev. 1335, 1352-56 (2004); Leila Nadya Sadat, Ghost Prisoners and Black Sites: Extraordinary Rendition Under International Law, 57 CASE W. RES. J. INT'L L. 309 (2006).

22 U.N. Comm. Against Torture, Consideration of Reports Submitted by States Parties Under Article 19 of the Convention: Conclusions and Recommendations of the Committee against Torture, United States of America, $\mid$ ๆ 17-18, U.N. Doc. CAT/C/USA/CO/2 (May, 18 2006), available at http://www.ohchr.org/english/bodies/cat/docs/AdvanceVersions/CAT.C.USA.CO.2. pdf [hereinafter CAT Report].

$23 \quad I d . \rrbracket 22$. 
Valparaiso University Law Review, Vol. 43, N 0.4 [2009], Art. 1

particular...torture and other prohibited treatment...."24 Additionally, the Security Council demanded that all parties to an armed conflict "comply strictly with the obligations applicable to them under international law, in particular those contained in the Hague Conventions of 1899 and 1907 and in the Geneva Conventions of 1949 ..." 25 The Security Council also stressed "the responsibility of States to comply with their relevant obligations to end impunity and to prosecute those responsible for war crimes, genocide, crimes against humanity and serious violations of international humanitarian law[,]"26 which can include the use of torture and cruel and inhumane treatment.

24 S.C. Res. 1674, ๆ 5, U.N. Doc. S/RES/1674 (Apr. 28, 2006).

25 Id. ๆ 6. See also S.C. Res. 1566, pmbl., U.N. Doc. S/RES/1566 (Oct. 8, 2004) (States must "ensure that any measures taken to combat terrorism comply with all their obligations under international law ... in particular international human rights, refugee, and humanitarian law[]").

26 S.C. Res. 1674, supra note 24, ๆ 8; see also S.C. Res. 1820, pmbl., U.N. Doc. S/RES/1820 (June 19, 2008) ("Reaffirming also the resolve expressed in the 2005 World Summit Outcome Document to eliminate all forms of violence against women and girls, including by ending impunity ..."); $\uparrow 4$ which states,

[R]ape and other forms of sexual violence can constitute a war crime, a crime against humanity, or a constitutive act with respect to genocide, stresses the need for the exclusion of sexual violence crimes from amnesty provisions .... and calls upon Member States to comply with their obligations for prosecuting persons responsible for such acts... and stresses the importance of ending impunity for such acts...

Id. See also S.C. Res. 1261, pmbl., U.N. Doc. S/RES/1261 (Aug. 25, 1999) (stressing "the responsibility of all States to bring an end to impunity and their obligation to prosecute those responsible for grave breaches of the Geneva Conventions ... " which include the use of torture). Concerning the customary international legal responsibility of all states aut dedere aut judicare to either initiate prosecution of or to extradite all persons reasonably accused of such crimes and other violations of customary international criminal law, see, e.g., JORDAN J. PAUST, M. CHERIF BASSIOUNI, ET AL., INTERNATIONAL CRIMINAL LAW 10, 12, 131-44, 155, 169 (3d ed. 2007); RUDIGER WOLFRUM \& DIETER FLECK, ENFORCEMENT OF INTERNATIONAL HUMANITARIAN LAW, reprinted in THE HANDBOOK OF INTERNATIONAL HUMANITARIAN LAW, 683-84 (Dieter Fleck Ed., 2d ed. 2008). See also supra notes 15-16; infra notes 28, 31-32 and accompanying text. Fulfillment of such legal requirements clearly would not be political. In fact, in the United States it is a presidential duty as well as that of a relatively independent Attorney General. See infra note 121.

Under international law, all states have the competence to prosecute such crimes; this is termed universal jurisdiction. See, e.g., RESTATEMENT, supra note 2, § 404; PAUST, BASSIOUNI, ET AL., supra at 155-74; JORDAN J. PAUST, INTERNATIONAL LAW AS LAW OF THE UNITED STATES 420-23, 432-41 (2d ed. 2003); PAUST, supra note 1, at 49, 167 n.155; Marlise Simons, Spanish Court Weighs Criminal Inquiry on Torture for 6 Bush-Era Officials, N.Y. TIMES, Mar. 29, 2009, at A6 (Spanish jurisdiction regarding at least complicity of Gonzales, Yoo, Addington, Feith, Bybee, and Haynes with respect to violations of Geneva law and the CAT at Guantanamo Bay would rest partly on universal jurisdiction.). Such a competence (as well as the duty to prosecute) was recognized early in U.S. history. See, e.g., United States v. Furlong, 18 U.S. (5 Wheat.) 184, 197 (1820) ("Robbery on the seas is considered as 
Article 146 of the 1949 Geneva Civilian Convention ${ }^{27}$ expressly and unavoidably requires that all Parties, including the United States, "search for persons alleged to have committed, or to have ordered to be committed,... grave breaches [of the Convention], and shall bring such persons, regardless of their nationality, before its own courts" for "effective penal sanctions" or, "if it prefers, ... hand such persons over for trial to another High Contracting Party ...."28 The obligation is absolute and applies with respect to alleged perpetrators of any status. As a party to the Geneva Conventions, the United States must either initiate prosecution or extradite an alleged perpetrator to another state or, today, render an accused to the International Criminal Court. "Grave

an offence within the criminal jurisdiction of all nations. It is against all, and punished by all ... within this universal jurisdiction."); United States v. Smith, 18 U.S. (5 Wheat.) 153, 161, 163 (1820) (piracy is "an offence against the universal law of society"); United States v. Klintock, 18 U.S. (5 Wheat.) 144, 147-48 (1820) (Piracy "is an offense against all. It is punishable in the Courts of all ... [our courts] are authorized and bound to punish[.]"); Talbot v. Janson, 3 U.S. (3 Dall.) 133, 159-60 (1795) (Iredell, J.) (“[A]ll . . trespasses against the general law of nations, are enquirable and may be proceeded against in any nation where no special exemption can be maintained, either by the general law of nations, or by some treaty which forbids or restrains it."), quoted in The Divina Pastora, 17 U.S. (4 Wheat.) 52, 65 (1819) (Marshall, C.J.); Ross v. Rittenhouse, 2 U.S. (2 Dall.) 160, 162 (Pa. 1792) ("universal law"); Respublica v. De Longchamps, 1 U.S. (1 Dall.) 111, 113, 115 (Pa. 1784) (assault against a foreign consul is a "crime against the whole world," a "crime against all other nations," and it is "the interest as well as the duty of the government, to animadvert upon ... conduct [in violation of the law of nations] with becoming severity"); Ex parte dos Santos, 7 F. Cas. 949, 953 (C.C.D. Va. 1835) (No. 4,016) (In his writings, Vattel noted the "duty of the sovereign to prevent ... and the consequent duty to punish of surrender[.]"); United States v. La Jeune Eugenie, 26 F. Cas. 832, 847-51 (C.C.D. Mass. 1821) (No. 15,551 (With respect to "an offence against the universal law of society," "no nation can rightly permit its subjects to carry it on, or exempt them ... [and] no nation can privilege itself to commit a crime against the law of nations."); 1 Op. Att'y Gen. 515 (1821) ("Crimes against the human family" are prosecutable by "[a]ll nations[]"); 1 Op. Att'y Gen. 68, 69 (1797) (a "violation of territorial rights ... [is] an offence against the law of nations ... [and] it is the interest as well as the duty of every government to punish"). Universal jurisdiction also provides a jurisdictional basis for support of any state's request for extradition. If a state cannot prosecute, its duty shifts to a duty to extradite.

27 Geneva Convention Relative to the Protection of Civilian Persons in Time of War, Aug. 12, 1949, 6 U.S.T. 3516, 75 U.N.T.S. 287 [hereinafter GC].

28 GC, supra note 27, at art. 146. See also HENCKAERTS \& DOSWALD-BECK, supra note 21, at 606-11; 4 COMmentary, GeneVA CONVENTION Relative to the PROTECTION OF CiVILIAN Persons in Time of WAR 587, 590, 597, 602 (ICRC, Jean S. Pictet ed. 1958); U.S. Dep't Army, FM 27-10, THE LAW OF LAND WARFARE 178, para. 499 ("The term 'war crime' is the technical expression for a violation of the law of war by any person or persons, military or civilian. Every violation of the law of war is a war crime[.]"), 181, I 506(b) (The requirements set forth in GC art. 146 "are declaratory of the obligation of belligerents under customary international law to take measures for the punishment of war crimes committed by all persons, including members of a belligerent's own armed forces.") (1956). 
breaches" of the Convention include "torture or inhuman treatment[]"29 and transfer of a non-prisoner of war from occupied territory. ${ }^{30}$ Similarly, Article 7, paragraph 1, of the Convention Against Torture expressly and unavoidably requires that a party to the treaty "under whose jurisdiction a person alleged to have committed ... [for example, torture or 'complicity or participation in torture,' is found, 'shall,'] if it does not extradite him, submit the case to its competent authorities for the purpose of prosecution." 31 There are no other alternatives.

When 160 states met in Rome in 1998 to create the International Criminal Court (ICC), they emphasized that there is a lack of immunity for international crimes such as genocide, other crimes against humanity, and war crimes, and affirmed the universal duty to end impunity and prosecute alleged perpetrators of such crimen contra omnes in international and domestic courts. For example, the preamble to the Statute of the ICC declares emphatically "that the most serious crimes of concern to the international community as a whole must not go unpunished and...their effective prosecution must be ensured by taking measures at the national level ...," expresses the determination of the community "to put an end to impunity for the perpetrators of these crimes ...," and recalls the fact "that it is the duty of every State to exercise its criminal jurisdiction over those responsible for international crimes ...." 32

With respect to Article 7 of the International Covenant on Civil and Political Rights, ${ }^{33}$ which mirrors customary human rights law and absolutely prohibits any form of torture and cruel, inhumane, and degrading treatment of any human being under any circumstances, ${ }^{34}$ the Human Rights Committee that functions under the auspices of the treaty had declared as early as 1982 that "[c]omplaints about ill-treatment must be investigated... [and] [t]hose found guilty must be held responsible[.]"35 Ten years later, the Committee reiterated the

\footnotetext{
Id. at art. 147.

Id. at arts. 49, 147; infra note 97.

CAT, supra note 20, at art. 7(1).

Rome Statute of the ICC, supra note 21, at pmbl.

International Covenant on Civil and Political Rights, 999 U.N.T.S. 171 (Dec. 9, 1966) [hereinafter ICCPR].

$34 \quad$ ICCPR, supra note 33, art. 7. Regarding the customary and non-derogable nature of such rights and prohibitions, see, e.g., PAUST, supra note 1 , at 820-21. The obligations also apply wherever the U.S. exercises effective control over a person of any status. See, e.g., id. at 142-43 n.40, 183-84 n.40. The same obligations apply through the U.N. Charter and are similarly universal. See supra note 6 and accompanying text. The obligations under the CAT are also universal. See, e.g., PAUST, supra note 1, at 173 n.1, 187 n.43, 199-200 n.145.

35 Office High Comm'n H.R., Report of the H.R. Comm., General Comment No. 7, $\llbracket 1,37$ U.N. GAOR, Supp. No. 40, Annex V, U.N. Doc. E/CN.4/Sub.2/Add.1/963 (May 5, 1982).
} 
requirement that those who violate Article 7, "whether [acts are] committed by public officials or other persons acting on behalf of the State, or by private persons[,]"36 and "whether by encouraging, ordering, tolerating or perpetrating prohibited acts, must be held responsible." 37 The Committee added that the State parties to the treaty have a duty to afford protection whether such acts are "inflicted by people acting in their official capacity, outside their official capacity[,] or in a private capacity." 38

A striking feature of every international criminal law treaty is that there is no recognition of any form of immunity for official elites. In fact, Article 27 of the Statute of the ICC expressly affirms that "official capacity as a Head of State or Government, a member of a Government or parliament, an elected representative or a government official shall in no case exempt a person from criminal responsibility" and that "[i]mmunities or special procedural rules which may attach to the official capacity of a person, whether under national or international law, shall not bar the Court from exercising its jurisdiction ... ." 39

\section{TYPES OF CRIMINAL RESPONSIBILITY FOR TORTURE}

At least four general types of criminal responsibility exist under international law with respect to torture and other outlawed treatment. First, it is obvious that direct perpetrators of violations of the Geneva

36 H.R. Comm., General Comment No. 20, ๆ 13, at 29-32, U.N. Doc. HRI/GEN/1 (Oct. 10,1992). See also infra note 65 (concerning private duties under human rights law).

$37 \quad I d$. 13 . As noted above, the responsibility to prosecute has been emphasized by the U.N. General Assembly and Security Council. See, e.g., supra notes 15-16, 26 and accompanying text.

$38 \quad I d$. $\mid 2$.

39 Rome Statute of the ICC, supra note 21, art. 27(1)-(2). See also The Prosecutor v. Milosevic, ICTY-99-37-PT, ๆ $26-34$ (Nov. 8, 2001) (the lack of immunity of heads of state for war crimes, genocide, and other crimes against humanity that is reflected in Article 7 of the Statute of the ICTY "reflects a rule of customary international law[]"); infra notes 59-60; text infra note 62 (perpetrators under the CAT who are not immune expressly include "a public official or other person acting in an official capacity[]"). The ICC's recognition that domestic immunities cannot obviate jurisdiction of the Court is an affirmation of the fact that under international law, no limiting domestic laws, amnesties, pardons, or grants of immunity would be entitled to any legal effect in another state or in any international forum. See, e.g., The Prosecutor v. Furundzija, ICTY-95-17/1-T (Dec. 10, 1998), paras. $153-$ 55 (stating that "national measures authorising [sic] or condoning torture or absolving its perpetrators through an amnesty law[]" would have no affect internationally); PAUST, supra note 1, at 202 n.150; PAUST, BASSIOUNI, ET AL., supra note 26, at 30, 34, 127-28, 132-34, 137$40,163,821$; infra note 85 . Furthermore, if legally operative limitations exist under domestic law of a particular state, its duty shifts from the duty to initiate prosecution to a duty to extradite or render an accused to an international tribunal. See also supra note 26; text infra notes 109-11. 
Valparaiso University Law Review, Vol. 43, No. 4 [2009], Art. 1

Conventions, other laws of war, the Convention Against Torture, and crimes against humanity (such as forced disappearance of persons) have direct liability. Leaders who issue authorizations, directives, findings, and orders that instruct others to commit acts that constitute international crimes, such as former President Bush and former Secretary of Defense Rumsfeld, may also be prosecuted as direct perpetrators of crimes. 40

Second, any person who aids and abets torture is liable as an aider and abettor before the fact, during the fact, or after the fact. ${ }^{41}$ Liability exists whether or not the person knows that his or her conduct is criminal or whether or not the conduct of the direct perpetrator of torture is criminal or even constitutes torture. ${ }^{42}$ Under customary international law, an aider and abettor need only be aware that his or her conduct (which can include inaction) would or does assist a direct

40 See, e.g., PAUST, BASSIOUNI, ET AL., supra note 26, at 32, 35, 51-73. See also infra notes 6972, 76, 78-80, 101-02. This and the next three paragraphs of this Article are borrowed from Jordan J. Paust, Prosecuting the President and His Entourage, 14 ILSA J. INT'L \& COMP. L. 539, 542-43 (2008). The following form of responsibility has been applied to cabinet officials:

A member of a Cabinet which collectively, as one of the principal organs of the Government, is responsible for the care of prisoners is not absolved from responsibility if, having knowledge of the commission of crimes ... and omitting or failing to secure the taking of measures to prevent the commission of such crimes in the future, he elects to continue as a member of the Cabinet. This is the position even though the Department of which he is in charge is not directly concerned with the care of prisoners. A Cabinet member may resign. If he has knowledge of ill-treatment of prisoners, is powerless to prevent future ill-treatment, but elects to remain in the Cabinet thereby continuing to participate in its collective responsibility for protection of prisoners he willingly assumes responsibility for any ill-treatment in the future.

Judgment of International Military Tribunal for the Far East (1948), reprinted in PAUST, BASSIOUNI, ET AL., supra note 26, at 53.

41 See, e.g., CAT, supra note 20, art. 4(1); PAUST, BASSIOUNI, ET AL., supra note 26, at 35, $44-$ 49; PAUST, supra notes 1, at 18, 24, 30, 165, 167, 185, 193, 199, 277.

42 See, e.g., Rome Statute of the ICC, supra note 21, arts. 25(3)(c)-(d), 30, 32(2). See also Prosecutor v. Kordic \& Cerkez, Case No. ICTY 95-14/2-A, Judgment, ๆ 311 (Dec. 17, 2004) (more generally, an accused need not know the "specific legal definition of each element of a crime.... It suffices that he was aware of the [relevant] factual circumstances...."); Guenael Mettraux, Crimes Against Humanity in the Jurisprudence of the International Criminal Tribunals for the Former Yugoslavia and for Rwanda, 43 HARV. INT'L L.J. 237, 297 n.323 (2002) (regarding the factual quality, the accused "need not have known that his or her act... amounted to an 'inhumane act' either in the legal or moral sense."); CAT Comm. Gen. Comm., supra note 1, para. 9 ("[E]lements of intent and purpose in article 1 do not involve a subjective inquiry into the motivations of the perpetrators, but rather must be objective determinations under the circumstances[.]"). 
perpetrator or facilitates conduct that is criminal. ${ }^{43}$ In any case, ignorance of the law is no excuse. Especially relevant in this respect are the criminal memoranda and behavior of various German lawyers in the German Ministry of Justice, high level executive positions outside the Ministry, and the courts in the 1930s and 1940s that were addressed in informing detail in United States v. Altstoetter (The Justice Case). ${ }^{44}$ Clearly, several memo writers and others during the Bush Administration abetted the "common, unifying" plan to use "coercive interrogation[,]" and their memos and conduct substantially facilitated its effectuation. ${ }^{45}$ Therefore, prosecution or extradition of several members of the former Bush Administration for criminal complicity would be on firm ground.

Third, individuals can also be prosecuted for participation in a "joint criminal enterprise," 46 which the International Criminal Tribunal for Former Yugoslavia has recognized can exist in at least two relevant forms: (1) where all the accused "voluntarily participated in one of the aspects of the common plan" and "intended the criminal result [whether or not they knew it was a crime], even if not physically perpetrating the

43 See, e.g., Almog v. Arab Bank, 471 F. Supp. 2d 257, 286-87 (E.D.N.Y. 2007); Prosecutor v. Blaskic, Case No. ICTY-95-14-T-A, Judgment, ๆ 50 (July 29, 2004) ("If he is aware that one of a number of crimes will probably be committed, and one of those crimes is in fact committed, he has intended to facilitate...that crime, and is guilty as an aider and abettor."); Prosecutor v. Furundzija, Case No. ICTY-95-17/1-T, Judgment \ 236, 236-38, 245-46, 249 (Dec 10, 1998) (requiring only "mere knowledge that his actions assist"); Prosecutor v. Kambanda, Case No. ICTR-97-23-S, Judgment, $\mid 39$ (Sept. 4, 1998) (complicity included refusals to oppose criminal conduct during "meetings of the Council of Ministers, cabinet meetings and meetings of prefets where the course of ... [illegal conduct was] actively followed" and use of directives that "encouraged and reinforced" conduct that was criminal); see supra text accompanying note 37. At the International Military Tribunal for the Far East concerning the Trial of Koiso, an ex-Prime Minister, guilt was established where the accused knew that treatment of prisoners "left much to be desired" and he had asked for a full inquiry but did not resign from office or act more affirmatively to stop illegal treatment. 2 JUDGMENT OF THE IMT FOR THE FAR EAST 1778-79 (1948). C $f$. Rome Statute of the ICC, supra note 21, art. 25(3)(c) ("For the purpose of facilitating the commission of such a crime, aids, abets or otherwise assists ...."). The forms of criminal complicity recognized in Kambanda and Koiso seem to be particularly relevant to meetings of former Vice President Cheney and other high level officials of the Bush Administration in the White House during 2002 and 2003. See infra notes 76-77.

44 See U.S. v. Altstoetter (The Justice Case); 3 TRIALS OF WAR CRIMINALS BeFORE THE NUREMBERG MilitARy TRIBUNALS Under CONTROL COUNCIL LAW NO. 10, 1058 (1951).

45 See, e.g., infra notes 76-80, 86-102. See also Simons, supra note 26 (possible indictments of Gonzales, Yoo, Addington, Feith, Bybee, and Haynes).

46 See, e.g., PAUST, BASSIOUNI, ET AL., supra note 26, at 32, 37-38; Allison Marston Danner, Joint Criminal Enterprise, in 3 INTERNATIONAL CRIMINAL LAW: ENFORCEMENT 483 (M. Cherif Bassiouni ed., 3 ed, 2008). 
crime[;]" 47 and (2) where "(i) the crime charged was a natural and foreseeable consequence of the execution of that enterprise, and (ii) the accused was aware that such a crime was a possible consequence of the execution of that enterprise, and, with that awareness participated in the enterprise." 48

Fourth, civilian or military leaders with de facto or de jure authority, such as former President Bush and former Secretary of Defense Rumsfeld, can also be liable for dereliction of duty with respect to acts of torture engaged in by subordinates when the leader (1) knew or should have known that subordinates were about to commit, were committing, or had committed international crimes; (2) the leader had an opportunity to act; and (3) the leader failed to take reasonable corrective action, such as ordering a halt to criminal activity or initiating a process for prosecution of all subordinates reasonably accused of criminal conduct. ${ }^{49}$

\section{THE RIGHT TO FAIR COMPENSATION}

In 2007 and 2008, the United Nations General Assembly stressed that "national legal systems must ensure that victims of torture and other cruel, inhuman or degrading treatment or punishment obtain redress, are awarded fair and adequate compensation and receive appropriate social and medical rehabilitation." 50 In 2005, the U.N. General Assembly had provided further detail concerning the right to an effective judicial remedy for victims of violations of human rights law ${ }^{51}$ and the type of

47 See, e.g., Prosecutor v. Brdanin, Case No. ICTY-99-36-T, Judgment, n.697 (Sept. 1, 2004). Concerning the Bush Administration's "common, unifying" plan to deny rights and protections under international law and to use unlawful interrogation tactics, see, e.g., infra notes 69-72, 76-80, 86-102.

48 Id. ๆ 265; Prosecutor v. Blaskic, Case No. ICTY-95-14-T-A, Judgment, ๆ 50 (July 29, 2004).

49 See, e.g., PAUST, BASSIOUNI, ET AL., supra note 26, at 51-89. The President of the United States and the Secretary of Defense, among others, have de jure command authority. Furthermore, this type of leader responsibility for dereliction of duty is part of customary international law that is part of the supreme law of the land in the United States. It has also been incorporated by reference in 10 U.S.C. $\$ 818$ (2000), which incorporates all violations of the laws of war as offenses against the laws of the United States. See, e.g., infra note 106. Leader responsibility incorporated through such a statute (then, through the same language found in the 1916 Articles of War) was recognized by the Supreme Court. In re Yamashita, 327 U.S. 1, 15-16 (1946); see also Prosecutor v. Delalic, Case No. ICTY-96-21-T, Judgment, I 338 (Nov. 16, 1998). It has also been used with respect to civil sanctions against leaders. See, e.g., Kadic v. Karadzic, 70 F.3d 232, 242 (2d Cir. 1995); Xuncax v. Gramajo, 886 F. Supp. 162, 171-72 (D. Mass. 1995); PAUST, VAN DYKE, MALONE, supra note 4 , at $25,367-70,373,382,385-88,440,449$.

50 U.N. G.A. Res. 63/166, supra note 8, at para. 18; Torture and Other Cruel, Inhuman or Degrading Treatment or Punishment, G.A. Res. 62/148, supra note 8, ๆ 13.

51 Basic Principles, supra note 15, ๆ 12. 
"[a]dequate, effective and prompt reparation," compensation, rehabilitation, and "[s]atisfaction" required under international law. ${ }^{52}$

The mandatory duty to provide fair compensation is set forth in Article 14 of the Convention Against Torture:

Each State Party shall ensure in its legal system that the victim of an act of torture obtains redress and has an enforceable right to fair and adequate compensation, including the means for as full rehabilitation as possible. In the event of the death of the victim as a result of an act of torture, his dependents shall be entitled to compensation. 53

Similar rights to an effective remedy, access to courts, and nonimmunity are guaranteed in Articles 2(3)(a) and 14(1) of the International Covenant on Civil and Political Rights, as emphasized in General Comments of the Human Rights Committee that operates under the auspices of the Covenant. ${ }^{54}$ They had also been reflected previously in Article 8 of the Universal Declaration of Human Rights, 55 which had mirrored customary patterns of expectation concerning customary roots of the right to an effective remedy in domestic courts for violations of human rights and other rights under international law..$^{56}$

Within the United States, Justice Breyer has recognized more generally that universal jurisdiction with respect to "torture, genocide, crimes against humanity, and war crimes[] ... necessarily contemplates

$52 \quad$ See id. at $\boldsymbol{\top}$ 甲 15-22.

53 CAT, supra note 20, art. 14(1).

54 See, e.g., ICCPR, supra note 33, arts. 2(3)(a), 14(1); Dubai Petroleum Co. v. Kazi, 12 S.W.3d 71, 82 (Tex. 2000) ("Article 14(1) requires all signatory countries to confer the right of equality before the courts to citizens of all other signatories... [t] he Covenant not only guarantees foreign citizens equal treatment in the signatories' courts, but also guarantees them equal access to these courts."); PAUST, VAN DYKE, MALONE, supra note 4, at 82-83, 340-42. Article 50 of the Covenant further mandates that all of " $[\mathrm{t}]$ he provisions of the present Covenant shall extend to all parts of federated States without any limitations or exceptions," thereby assuring that rights and duties under the treaty apply with respect to decisions and conduct in Washington, D.C. as well as in judicial proceedings within the United States. As part of human rights law, rights to an effective remedy and access to courts are also necessarily part of the U.N. Charter-based obligations of all members of the U.N. to assure "universal respect for, and observance of," human rights. See also supra note 6.

55 Universal Declaration of Human Rights, G.A. Res. 217A, at art. 8, U.N. Doc. A/810 (Dec. 10, 1948) ("Everyone has the right to an effective remedy by the competent national tribunals for acts violating [human rights] ....").

56 See, e.g., PAUST, supra note 26, at 224-29. 
Valparaiso University Law Review, Vol. 43, N0. 4 [2009], Art. 1

a significant degree of civil tort recovery," 57 and a remarkable number of U.S. cases have recognized the right to civil remedies for torture and/or cruel, inhuman, and degrading treatment. ${ }^{58}$ Several cases have also

57 Sosa v. Alvarez-Machain, 542 U.S. 692, 762, 124 S.Ct. 2739, 2783 (2004) (Breyer, J., concurring).

58 See, e.g., Hilao v. Estate of Ferdinand Marcos, 103 F.3d 767 (9th Cir. 1996); Abebe-Jira v. Negewo, 72 F.3d 844 (11th Cir. 1996); Kadic v. Karadzic, 70 F.3d 232, 242-43, 245 (2d Cir. 1995), cert. denied, 518 U.S. 1005 (1996); Siderman de Blake v. Republic of Argentina, 965 F.2d 699, 717 (9th Cir. 1992), cert. denied, 507 U.S. 1017 (1993); Filartiga v. Pena-Irala, 630 F.2d 876 (2d Cir. 1980); Presbyterian Church of Sudan v. Talisman Energy, Inc., 244 F. Supp. 2d 289, 305-06 (S.D.N.Y. 2003); Cabello Barrueto v. Larios, 205 F. Supp. 2d 1325, 1333 (S.D. Fla. 2002); Mehinovic v. Vuckovic, 198 F. Supp. 2d 1322, $1344-49$ (N.D. Ga. 2002); Estate of Cabello v. Fernandez-Larios, 157 F. Supp. 2d 1345, 1360-61 (S.D. Fla. 2001); Jama v. I.N.S., 22 F. Supp. 2d 353, 363 (D.N.J. 1998); Doe v. Islamic Salvation Front, 993 F. Supp. 3, 8 (D.D.C. 1998) (including that covered under common Article 3 of the Geneva Conventions); In re Estate of Ferdinand E. Marcos Human Rights Litigation, 910 F. Supp. 1460, 1462-63 (D. Haw. 1995); Xuncax v. Gramajo, 886 F. Supp. 162, 187 (D. Mass. 1995); Paul v. Avril, 812 F. Supp. 207 (S.D. Fla. 1993); see also PAUST, supra note 1, at 165 n.154; infra notes 69, 72-73; Jean-Marie Henckaerts, Study on Customary International Humanitarian Law: A Contribution to the Understanding and Respect for the Rule of Law in Armed Conflict, $87 \mathrm{INT}^{\prime} \mathrm{L}$ REV. RED CROSS 175, 196 (2005) (“[A] State is responsible for violations of international humanitarian law ... and is required to make full reparation for the loss or injury caused by such violations[.]").

Section 5 of the 2006 Military Commissions Act (MCA) attempts to deny use by any person of "the Geneva Conventions or any protocols thereto in any ... civil action or proceeding to which the United States, or a current or former officer, employee, member of the Armed Forces, or other agent of the United States is a party as a source of rights in any court of the United States or its States or territories." Pub. L. No. 109-366, 120 Stat. 2600, 2631-32 (2006) (codified at 28 U.S.C. § 2241(2000)) [hereinafter MCA]. Importantly, the language does not attempt to deny use of customary international law reflected in Geneva law, deny use of the 1907 Hague Convention No. IV on the laws of war, deny use of any other customary laws of war, deny use of related treaty-based or customary human rights law, deny use of Article 14 of the Convention Against Torture, or deny use of any other federal statute as a "source of rights," e.g., the Alien Tort Claims Act (ATCA), 28 U.S.C. $\S 1350$ (2000) or Torture Victim Protection Act (TVPA) Pub. L. No. 102-256, 106 Stat. 73 (1992); Antiterrorism Act (ATA), 18 U.S.C. § 2333 (2000). In any event, it is clear that Congress has no power to obviate the original jurisdiction of the Supreme Court. See also Durousseau v. United States, 10 U.S. 307, 314 (1810) (“The appellate powers of this court are ... [not created by statute but] are given by the constitution."); Hamdan v. Rumsfeld, 548 U.S. 557, 575 (2006) (citing Durousseau). Concerning the attempted reach of the 2006 Act, see also Paust, Above the Law, supra note 1, at 414-15.

Congress has no power to violate the separation of powers by such a blatant denial of a constitutionally mandated, traditional, and essential judicial power to implement treaty law of the United States that, as the Constitution expressly requires, 'shall extend to all cases... arising under... treaties.

Id. (ellipses in original).

The violation of the separation of powers in this instance is especially evident where federal courts have continuing jurisdiction in all cases arising under treaties and Congress attempts to substantially inhibit 
Paust: The Absolute Prohibition of Torture and Necessary and Appropriate

recognized the unavoidable fact that violations of international criminal law and human rights law cannot be lawful "official" or "public" acts of the state and are not entitled to immunity. ${ }^{59}$ As the International

judicial independence by controlling the results in certain cases. Congress is attempting precisely that by prescribing rules for decision in a particular way or, in this instance, rights and rules of law contained in the Geneva Conventions that cannot be used for decision. This congressional effort to deny use of particular law and to control judicial decision of cases in a particular way is all the more blatant where Congress has attempted to deny judicial use of common article 3 as a rule for decision in detainee cases after the Supreme Court clearly decided that common article 3 is a primary rule for decision. Additionally, Congress has no power to deny to the States of the United States their shared constitutionally based duty and authority to implement treaty law of the United States as supreme law of the land.

Id. at 415. If otherwise operative, this provision of the MCA would be trumped in any event by the "rights under" treaties and/or the law of war exceptions to the last in time rule documented in various Supreme Court and other federal cases. See id. at 379-80; nn.91-92, 196, 211, 412, 418 (also addressing MCA Section 7(a)).

59 See, e.g., Sarei v. Rio Tinto, PLC, 487 F.3d 1193, 1210 (9th Cir. 2007) (“[A]cts of racial discrimination cannot constitute official sovereign acts," also quoting Siderman de Blake v. Republic of Argentina, 965 F.2d 699, 718 (9th Cir. 1992) ("International law does not recognize an act that violates jus cogens as a sovereign act[.]")); Enahoro v. Abubakar, 408 F.3d 877, 893 (7th Cir. 2005) (Cudahy, J., dissenting) (“[O]fficials receive no immunity for acts that violate international jus cogens human rights norms (which by definition are not legally authorized acts)."); Doe I v. Unocal Corp., 395 F.3d 932, 958-59 (9th Cir. 2002); Altmann v. Republic of Argentina, 317 F.3d 954, 967 (9th Cir. 2002), quoting West v. Multibanco Comermex, S.A., 807 F.2d 820, 826 (9th Cir. 1987) ("violations of international law are not 'sovereign' acts"); In re Estate of Ferdinand Marcos, Human Rights Litigation Hilao v. Estate of Ferdinand Marcos, 25 F.3d 1467, 1471 (9th Cir. 1994) (human rights violations, including torture, are not lawful public acts of a state); Liu v. Republic of China, 892 F.2d 1419, 1432-33 (9th Cir. 1989), cert. denied, 497 U.S. 1058 (1990) (act of state doctrine not applied to assassination, which is not in the "public interest" and a strong international consensus exists that it is illegal); Bowoto v. Chevron Corp., 2007 WL 2349345 (N.D. Cal. 2007) (quoting Siderman, quoted above in Sarei); Presbyterian Church of Sudan v. Talisman Energy, Inc., 244 F. Supp. 2d at 344-35 (adjudication of genocide, war crimes, enslavement, and torture is not barred by the act of state doctrine); Cabiri v. Assasie-Gyimah, $921 \mathrm{~F}$. Supp. 1189, 1198 (S.D.N.Y. 1996) (defendant could not argue that torture fell within the scope of his authority); Xuncax v. Gramajo, 886 F. Supp. at 176 (quoting Letelier v. Republic of Chile, 488 F. Supp. 665, 673 (D.D.C. 1980)) ("[T] hese actions exceed anything that might be considered to have been lawfully within the scope of Gramajo's official authority," and "assassination is 'clearly contrary to the precepts of humanity as recognized in both national and international law' and so cannot be part of official's 'discretionary' authority[.]"); Paul v. Avril, 812 F. Supp. at 212 (Defendant's argument regarding "the act of state and political question doctrines is completely devoid of merit. The acts... [of torture, cruel, inhuman and degrading treatment, and arbitrary detention in violation of customary international law] hardly qualify as official public acts" and regarding the political question doctrine, the claims present "clearly justiciable legal issues[.]"); Forti v. Suarez-Mason, 672 F. Supp. 1531, 1546 (N.D. Cal. 1987) (noting that torture, arbitrary detention, and summary execution "are not the public official acts"); see also ICCPR, supra 
Valparaiso University Law Review, Vol. 43, N0. 4 [2009], Art. 1

note 33, art. 2(3)(a) (non-immunity is required by treaty because the mandated right to an effective judicial remedy exists "notwithstanding that the violation has been committed by persons acting in an official capacity"); CAT, supra note 20, art. 14(1) (the treaty-based requirement of fair compensation necessarily applies to acts of public officials covered under Article 1); Johnson v. Eisentrager, 339 U.S. 763, 765, 789 (1950) (no form of immunity exists for war crimes in violation of Geneva law); Berg v. British and African Steam Navigation Co. (The Prize Ship “Appam”), 243 U.S. 124, 153-56 (1917) (jurisdiction recognized regarding German government's violation of the law of nations and relevant treaties, and nonimmunity existed because "an illegal capture would be invested with the character of a tort" [id. at 154] and jurisdiction is not obviated despite the intervention of the German ambassador and a claim that since proceedings had been instituted in Germany, the U.S. court should decline. Id. at 147, 152.); The Santissima Trinidad, 20 U.S. (7 Wheat.) 283, 350-55 (1822) (property taken by a foreign ship of war in violation of the law of nations is not immune and "is liable to the jurisdiction of our Courts" and if the sovereign "comes personally within our limits, ... he may become liable to judicial process in the same way"); Abebe-Jira v. Negewo, 72 F.3d at 848 (regarding the political question doctrine, "[i]n Linder v. Portocarrero, 963 F.2d 332, 337 (11th Cir.1992), we held that the political question doctrine did not bar a tort action instituted against Nicaraguan contra leaders [for war crimes in violation of common Article 3 of the Geneva Conventions]. Consequently, we reject Negewo's contention in light of Linder"); Daventree, Ltd. v. Republic of Azerbaijan, 349 F. Supp.2d 736, 755 n.4 (S.D.N.Y. 2004) ("the Act of State doctrine only applies to valid acts of state"); Doe I v. Unocal Corp., 963 F. Supp. 880, 894-95 (C.D. Cal. 1997) (

Because nations do not, and cannot under international law, claim a right to torture..., a finding that a nation has committed such acts ... should have no detrimental effect on the policies underlying the act of state doctrine. Accordingly, the Court need not apply the act of state doctrine in this case[.]

); United States v. La Jeune Eugenie, 26 F. Cas. 832, 847-51 (C.C.D. Mass. 1821) (No. 15,551) (regarding "an offence against the universal law of society," "no nation can rightly permit its subjects to carry it on, or exempt them[,]... [and] no nation can privilege itself to commit a crime against the law of nations"); S. REP. NO. 102-249, at 3-4, 8 (1991) (the act of state doctrine "applies only to 'public' acts, and no state commits torture as a matter of public policy" and "[a] state that practices torture and summary execution is not one that adheres to the rule of law. Consequently, the Torture Victim Protection Act (TVPA) is designed to respond to this situation by providing a civil cause of action in U.S. courts ..." and "[the Senate Judiciary] committee does not intend the 'act of state' doctrine to provide a shield from lawsuit”); H.R. Comm., General Comment No. 20, supra note 36, paras. 2, 13, 15 (victims have a "right to an effective remedy, including compensation" whether violators of Article 7 were "public officials or other persons acting on behalf of the State, or by private persons" "acting in their official capacity, outside their official capacity or in a private capacity[]"); 9 Op. Att'y Gen. 356, 357 (1859) (“A sovereign who tramples upon the public law of the world cannot excuse himself by pointing to a provision of his own municipal code[.]"); PAUST, supra note 1, at 166 n.154 (also demonstrating why there should be no substitution of the United States as the defendant in civil actions brought against former U.S. officials regarding international crimes because under international law such criminal conduct is outside "the scope of ... official duties," international law is a recognized background for interpretation of federal statutes, and two treaties denying any form of immunity are subsequent in time to two prior federal statutes regarding substitution). 
international criminal law (such as violations of the laws of war) are ultra vires or beyond the lawful authority of any state or official:

[T] he doctrine of the sovereignty of the State... cannot be applied to acts which are condemned as criminal by international law. The authors of these acts cannot shelter themselves behind their official position... He who violates the laws of war cannot obtain immunity while acting in pursuance of the authority of the state if the state in authorizing action moves outside its competence under international law. ${ }^{60}$

As noted more particularly in Filartiga $v$. Pena-Irala with respect to torture, "the torturer has become-like the pirate and slave trader before him-hostis humani generis, an enemy of all mankind." 61

\section{WHAT IS TORTURE?}

The Convention Against Torture and Other Cruel, Inhuman or Degrading Treatment or Punishment provides a lengthy definition of torture. Article 1, paragraph 1 of the treaty declares:

For the purposes of this Convention, the term "torture" means any act by which severe pain or suffering, whether physical or mental, is intentionally inflicted on a person for such purposes as obtaining from him or a third person information or a confession, punishing him for an act he or a third person has committed or is suspected of having committed, or intimidating or coercing him or a third person, or for any reason based on discrimination of any kind, when such pain or suffering is inflicted by or at the instigation of or with the consent or acquiescence of a public official or other person acting in an official capacity. It does not include pain or suffering arising only from, inherent in or incidental to lawful sanctions. ${ }^{62}$

\footnotetext{
60 Judgment and Opinion, International Military Tribunal (Nuremberg) (Oct. 1, 1946). Regarding nonimmunity, see also PAUST, BASSIOUNI, ET AL., supra note 26, at 29-34, 36-43, 131-34, 138-40, 168-70, 207, 355, 427; Inter-American Convention on the Forced Disappearance of Persons, supra note 21, art. IX; supra notes 14, 39 and accompanying text. $61 \quad 630$ F.2d at 890.

62 CAT, supra note 20, art. 1(1). See also Rome Statute of the ICC, supra note 21, art.
} 
Valparaiso University Law Review, Vol. 43, No. 4 [2009], Art. 1

Article 1 also acknowledges that "[t]his article is without prejudice to any international instrument or national legislation which does or may contain provisions of wider application." 63 Therefore, there is implicit recognition that the treaty's definition might be too limited. In fact, many recognize that human rights law also prohibiting torture and cruel, inhumane and degrading treatment ${ }^{64}$ is not limited to official perpetrators or to those who act at their instigation or with their consent or acquiescence and that private perpetrators can commit illegal acts of torture. 65 Most agree, however, that prohibited acts of "torture" involve (1) an intentional act, and (2) "severe" pain or suffering, whether the prohibition is found, for example, in the CAT, human rights law, or the laws of war. ${ }^{66}$ The severe pain or suffering, whether physical or mental, does not have to be long lasting, damage health, or produce any identifiable bodily injury.

As noted above, a widespread recognition exists that under international law there are no exceptional circumstances that can justify the use of torture as a matter of law. Similarly, there are no temporal or geographic gaps with respect to the prohibition of torture and it applies regardless of the status of the direct victim of torture, for example, whether or not the victim is an alleged criminal, enemy, or terrorist.

7(2)(e) (similar definition of torture as a crime against humanity); 18 U.S.C. § 2340(1) (2006) ("'torture' means an act ... specifically intended to inflict severe physical or mental pain or suffering").

63 CAT, supra note 20, art. 1(1).

64 See, e.g., ICCPR, supra note 33, art. 7; American Convention on Human Rights, art. 5, O.A.S. Treaty Ser. No. 36 (1969), 144 U.N.T.S. 123; American Declaration of the Rights and Duties of Man, arts. I ("security of his person"), XXV ("humane treatment"), O.A.S. Res. XXX (1948), O.A.S. Off. Rec. OEA/Ser.L/V/I.4 Rev. (1965); Universal Declaration of Human Rights, supra note 55, art. 5.

65 Concerning private duties under human rights law, see, e.g., ICCPR, supra note 33, pmbl., art. 5(1); American Convention on Human Rights, supra note 64, arts. 29(a), (d), 32(1); American Declaration, supra note 64, pmbl., Ch. Two ("Duties"); Universal Declaration, supra note 55, pmbl., arts. 1, 29(1), 30; H.R. Comm., General Comment No. 20, supra note 36; Declaration on Measures to Eliminate Terrorism, G.A. Res. 49/60, Annex, prmbl, U.N. Doc. A/Res/49/60 (Dec. 9, 1994) (addressing "links between terrorist groups and drug traffickers and their paramilitary gangs, which have resorted to all types of violence, thus ... violating basic human rights"), I 2 ("Acts, methods and practices of terrorism ... aim at the destruction of human rights[.]"). Ireland v. United Kingdom, 25 Eur. Ct. H.R. (Ser. A), I 149 (1978) ("[T]errorist activities ... of individuals or of groups ... are in clear disregard of human rights."); Jordan J. Paust, The Other Side of Right: Private Duties Under Human Rights Law, 5 HARV. HUM. RTS. J. 51 (1992); Jordan J. Paust, Human Rights Responsibilities of Private Corporations, 35 VAND. J. TRANSNAT'L L. 801 (2002); Jordan J. Paust, The Reality of Private Rights, Duties, and Participation in the International Legal Process, 25 Mich. J. INT'L L. 1229, 1241-45 (2004); text supra notes 36, 38.

66 See, e.g., Paust, Executive Plans, supra note 1, at 845-46 \& nn.127, 129; see also Paust, Above the Law, supra note 1, at 408 n.174, 410 n.181; supra note 62 and accompanying text. 
Article 2, paragraph 2 of the CAT is emblematic of a widely shared understanding in this regard: "No exceptional circumstances whatsoever, whether a state of war or a threat of war, internal political in stability or any other public emergency, may be invoked as a justification of torture." 67 Furthermore, Article 2, paragraph 3, affirms that "[a]n order from a superior officer or a public authority may not be invoked as a justification of torture." 68 It is simply beyond the question that an act of torture cannot constitute a lawful sovereign or public act of any state.

\section{UNLAWFUL TACTICS USED DURING THE BUSH ADMINISTRATION}

Among specific interrogation tactics used on detained persons and authorized by President Bush and/or Secretary Rumsfeld, Secretary Rice, Attorney General Ashcroft, and several others within the Bush Administration that manifestly and unavoidably constitute torture are water-boarding or a related inducement of suffocation, ${ }^{69}$ use of dogs to

67 CAT, supra note 20, art. 2(2). Quite clearly, war is not an excuse and the CAT expressly applies during a war. In any event, the same prohibition applies under the laws of war, human rights law (which also applies in time of war), the U.N. Charter (which applies universally and in all social contexts), and customary norms jus cogens (same). See supra notes 1-6. Importantly, there is no so-called lex specialis limitation or obviation of the reach of any relevant treaty or customary international law regarding freedom from torture and cruel, inhuman, or degrading treatment. In fact, the phrase lex specialis appears in no treaty identifying international criminal conduct and in no human rights treaty. To claim that the CAT does not apply when the laws of war apply is patent nonsense. See PAUST, supra note 1, at 173 n.1 (quoting the U.N. Committee Against Torture that the CAT "applies at all times, whether in peace, war or armed conflict"), 187 n.43. Furthermore, as a matter of law, there is no necessity defense. See also Memorandum from the Office of Legal Counsel, Dep't of Justice, to James B. Comey, Deputy Attorney General, Re: Legal Standards Applicable Under 18 U.S.C. §§ 2340-2340A, at 17 (Dec. 30, 2004) (noting with respect to the U.S. torture statute that "a defendant's motive (to protect national security, for example) is not relevant"), available at http://www.usdoj.gov/olc/18usc23402340a2. htm.

68 Id. art. 2(3). See also CAT Comm. Gen. Comm., supra note 1, para. 26 ("subordinates may not seek refuge in superior authority and should be held to account individually").

69 See, e.g., Hudson v. McMillian, 503 U.S. 1, 26 (1992) (Thomas, J., dissenting) ("water torture" violates the Eighth Amendment, quoting Williams v. Boles, 841 F.2d 181, 183 (7th Cir. 1988)); Coleman v. Alabama, 399 U.S. 1, 16 n.3 (1970) (Douglas, J., concurring) (forms of torture include "dripping water on the head," "intense noise to prevent sleep," and "threats to shoot or kill the victim"); Robinson v. California, 370 U.S. 660, 669 (1962) (Douglas, J., concurring) ("water cures" are "terror"); Abdel-Rahman v. Gonzales, 493 F.3d 444, 448 (4th Cir. 2007) ("various types of torture, including simulated drownings" claimed); Don v. Gonzales, 476 F.3d 738, 753 (9th Cir. 2007) (Wardlaw, J., dissenting) ("methods of torture" include "near drownings," quoting the 2001 U.S. Dep't of State, Country Report on Human Rights Practices for Sri Lanka); Hernandez-Barrera v. Ashcroft, 373 F.3d 9, 15 (1st Cir. 2004) ("water torture" claimed); United States v. Yousef, 327 F.3d 56, 126-27 (2d Cir. 2003) ("torture" would include "simulated drowning" if proved); United States v. Galindo-Davalos, 215 F.3d 1338 (10th Cir. 2000) ("tehuacanazo, a form of torture 
Valparaiso University Law Review, Vol. 43, No. 4 [2009], Art. 1

which involves pouring a carbonated beverage into a suspect's sinuses"); Ratnam v. I.N.S., 154 F.3d 990, 992 (9th Cir. 1998) ("torture[,]" to extract information from a suspected terrorist, included having the suspect "tipped upside down and his head immersed in a drum of water"); Hilao v. Estate of Marcos, 103 F.3d 789, 790 (9th Cir. 1996) ("water torture" occurred through use of a towel over the nose and mouth and water poured down the nostrils to induce the fear of drowning); United States v. Lee, 744 F.2d 1124, 1125 (5th Cir. 1984) (civil rights of prisoners violated when they were subjected to "water torture"); United States v. Schmidt, 573 F.2d 1057, 1068-69 (9th Cir. 1978) (Hufstedler, J., concurring and dissenting) (where Peruvians "forced his head into a bucket of water" and gave a "promise of greater tortures," confession was "extracted by torture"); Cooley v. Weinberger, 518 F.2d 1151, 1153 (10th Cir. 1975) ("torture and abuse, including the "water treatment'”); Iva Ikuko Toguri D'Aquino v. United States, 192 F.2d 338, 361 (9th Cir. 1951) ("water torture" used by Japanese during WWII); Mendoza v. I.N.S., 11 Fed. Appx. 888, 890, 2001 WL 399446 (9th Cir. 2001) (form of torture includes “'la tina,' involving the repeated head-first submersion of suspected terrorists in water"); Struble v. Fountain, 2008 WL 2074151, at *3 (S.D. Miss. 2008) ("simulated drowning" is "egregious" and can warrant punitive damages); Yousuf v. Samantar, 2007 WL 2220579, at *3 n.7 (E.D. Va. 2007) ("[w]aterboarding is a form of torture"); Kaweesa v. Ashcroft, 345 F. Supp. 2d 79, 86 (D. Mass. 2004) ("water torture" during Idi Amin's regime in Uganda); In re Estate of Ferdinand E. Marcos Human Rights Litig., 910 F. Supp. 1460, 1463 (D. Haw. 1995) ("forms of torture" include "[t]he "water cure," where a cloth was placed over the detainee's mouth and nose, and water poured over it producing a drowning sensation"); Benjamin v. Jacobson, 935 F. Supp. 332, 339 (S.D.N.Y. 1996) (addressing "water torture" in prisons); In re Grand Jury Proceedings, 432 F. Supp. 1278, 1281 (D.N.C. 1977) (discussing "types of torture ... such as ... the water treatment"); State v. Piper, 709 S.W.2d 783, 799 (S.D. 2006) (torture occurred when person "stripped the victim of his clothes," "forced the victim into freezing temperatures and snow and icy water[,]" and the victim "endured drowning attempts"); People v. Joiner, 2006 WL 3598520 (Cal. App. 4 Dist. 2006) (“drowning as a form of torture"); People v. Devin, 93 Ill.2d 326, 348, 444 N.E.2d 102, 113 (Ill. 1982) (discussing "torture called the 'gag treatment' in which some type of liquid detergent mixed with water is poured into a person's mouth until the individual chokes"); Fisher v. State, 145 Miss. 116, 110 So. 361, 362 (1926) ("water cure, a specie of torture well known to the bench and bar of the country"); White v. State, 129 Miss. 182, 91 So. 903, 904 (1922) ("water cure" causes "pain and horror" and is "barbarous"); Commonwealth v. Chaitt, 380 Pa. 532, 555, 112 A.2d 379 (1955) ("[t] here was a time when the rack, the dungeon, the water-cure and the thumbscrew were used"); Cavazos v. State, 143 Tex. Crim. 564, 566, 160 S.W.2d 260 (1942); Saadi v. Italy, [2008] ECHR 37201/06, para. 143 (Eur. Ct. H.R. Feb. 28, 2008) ("immersion of the head in water .... undoubtedly reach[es] the level of severity required" to constitute torture); Baldeón-Garcia v. Peru, 2006 Inter-Am. Ct. H.R. (ser. C) No. 147, at paras. 123, 125 (Apr. 6, 2006) (treatment involving beatings and being "submerged in water tanks" "constitutes an act of torture"); Tibi v. Ecuador, 2004 InterAm. Ct. H.R. (ser. C) No. 114, at paras. 148-49 (Sept. 7, 2004) (where victim's "head was submerged in a water tank" and "victim was threatened .... [a]ll this is a form of torture"); RICHARD L. LAEL, THE YAMASHITA PRECEDENT: WAR CRIMES AND COMMAND RESPONSIBILITY 80-84 (Scholarly Resources Inc. 1982) (documenting forms of "Japanese torture, including the water cure," used in the Philippines during WWII); PAUST, supra note 1, at 13, 16, 28, 43, 150, 152, 161, 173, 178-79; David Abraham, The Bush Regime from Elections to Detentions: A Moral Economy of Carl Schmitt and Human Rights, 62 U. MiAMI L. Rev. 249, 267 (2008) (quoting the Nazi Minister of Justice with respect to an indictment of German accused regarding use of water torture in a concentration camp: "The nature of the assault, especially the use of water torture, reveals a brutality and cruelty on the part of the 
Paust: The Absolute Prohibition of Torture and Necessary and Appropriate

create intense fear, ${ }^{70}$ threatening to kill the detainee or family members, ${ }^{71}$ and the cold cell or a related inducement of hypothermia. ${ }^{72}$ With respect

perpetrator that is alien to German sensibilities and feelings."); Scott Horton, Kriegsraison or Military Necessity? The Bush Administration's Wilhelmine Attitude Towards the Conduct of War, 30 FORDHAM INT'L L.J. 576, 593-94 (2007) (regarding 1902 U.S. courts-martial in the Philippines and a 1968 U.S. court-martial in Vietnam); Jamie Mayerfield, Playing By Our Own Rules: How U.S. Marginalization of International Human Rights Law Led to Torture, 20 HARV. HUM. RTS. J. 89 (2007); Manfred Nowak, What Practices Constitute Torture: US and UN Standards, 28 HUM. RTS. Q. 809, 829 (2006) (plastic bag over the head to simulate asphyxiation); Major Mynda G. Ohman, Integrating Title 18 War Crimes Into Title 10: A Proposal to Amend the Uniform Code of Military Justice, 57 A. F. L. REV. 1, 18 nn.78-79 (2005) (regarding 1902 U.S. courts-martial); Evan Wallach, Drop by Drop: Forgetting the History of Water Torture in U.S. Courts, 45 COLUM. J. TRANSNAT'L L. 468 (2007) (addressing, among others, convictions in the IMT for the Far East, Norway, the U.K. in Singapore, U.S. military commissions after WWII, and U.S. courts-martial in the Philippines in 1902); Walter Pincus, Waterboarding Historically Controversial; In 1947, the U.S. Called It a War Crime; In 1968, It Reportedly Caused an Investigation, WASH. POST, Oct. 5, 2006, at A17; Evan Wallach, Waterboarding Used to Be a Crime, WASH. POST, Nov. 4, 2007, at B1 ("After World War II, we convicted several Japanese soldiers for waterboarding;" at the I.M.T. for the Far East, "[t]he principal proof upon which their torture convictions were based was" water-boarding; U.S. soldiers were "court-martialed for using the "water cure'" during U.S. occupation of the Philippines during the Spanish-American War; in 1982, federal charges against a Texas sheriff and three deputies "alleged that they conspired to 'subject prisoners to a suffocating water torture ordeal in order to coerce confessions[.]'"); Tactic Called Torture, N.Y. TIMES, Feb. 9, 2008, at A8 (U.N. High Commissioner for Human Rights Louise Arbour notes that waterboarding is torture in violation of the CAT); Brian Ross \& Richard Esposito, CIA's Harsh Interrogation Techniques Described, $\mathrm{ABC}$ News (Nov. 18, 2005), available at http://abcnews.go.com/WNT/Investigations/story?id=1322866; U.S. Dep't of State, 1999 Country Reports on Human Rights Practices: Kenya ("torture" method included "deprivation of air by submersion of the head in water"), available at http://www.state.gov/www/global/human_rights/1999_hrp_report/Kenya.html; id., Libya ("torture" included "suffocating with plastic bags"); $i d$. ., Russia (torture tactics included "asphyxiation using gas masks or bags"); id., Sri Lanka (methods of torture include "near drownings"); id., Tunisia ("torture" included "submersion of the head in water"); id., Turkey (methods of torture include "water dripped onto the head, ... near suffocation by placing bags over the head"); id., Uzbekistan (torture includes "near suffocation"); U.S. Dep't of Army Subject Schedule 27-1, The Geneva Conventions of 1949 and Hague Convention No. IV of 1907, at 7 (Oct. 8, 1970) (illegal means of interrogation of a detainee include "dunking his head into a barrel of water, or putting a plastic bag over his head to make him talk," adding, "No American soldier can commit these brutal acts, nor permit his fellow soldiers to do so."); infra note 76, 83. Quoted language from the 1999 Country Reports cited in this footnote and infra notes 71-72 is essentially the same in the State Department's 2002 and 2003 Country Reports with the exception of Egypt infra note 72) and most appear in the 2004 Reports. These can be compared through the website http://www.state.gov/g/drl/rls/hrrpt.

70 See, e.g., PAUST, supra note 1, at 12-16, 25-27, 43, 155, 159-62, 173-75, 256; Bob Woodward, Detainee Tortured, Says U.S. Official, WASH. POST, Jan. 14, 2009, at A1 (noting that Susan J. Crawford, the convening authority of the GTMO military commissions, dropped charges against Mohammed al-Qahtani because "[h]is treatment met the legal definition of torture," which involved a combination of threatening "with a military working dog," stripping naked, subjecting to extreme cold, sexual humiliation, and 
Valparaiso University Law Review, Vol. 43, N0. 4 [2009], Art. 1

allowing little sleep for many days); see also Rasul v. Rumsfeld, 414 F. Supp.2d 26, 27 (D.D.C. 2006) (allegations of "various forms of torture, which include hooding, forced nakedness, .... subjection to extremes of heat and cold, .... and the use of unmuzzled dogs for intimidation"); Haitian Refugee Center v. Civiletti, 503 F. Supp. 442, 493 (D. Fla. 1980) ("method of torture" included use of dogs eating cadavers at night whereby "the sinister barking of the dogs would take sleep away from all prisoners"); Chitayev and Chitayev v. Russia, [2007] ECHR 59334/00, para. 159 (Eur. Ct. H.R. Jan. 18, 2007) ("the illtreatment at issue [where "dogs were set on them"] ... . amounted to torture").

71 See, e.g., Coleman v. Alabama, 399 U.S. at 16 n.3 (quoted supra note 69); Tourchin v. Attorney General of the U.S., 277 Fed. Appx. 248, 252, 2008 WL 1962273 (3d Cir. 2008) (claim of likelihood of torture addressed in the CAT was supported by past torture of an alien and death threats against alien's loved ones made by the KGB, also quoting 8 C.F.R. $\S$ 208.18(a)(4)(iii)-(iv), which notes that torture includes "[t]he threat of imminent death; or [t] he threat that another person will imminently be subjected to death, severe physical pain or suffering"); Comollan v. Ashcroft, 378 F.3d 694, 697 (7th Cir. 2004) (threat of imminent death is a form of torture); Massie v. Government of Democratic People's Republic of Korea, _ F. Supp.2d _ , 2008 WL 5423028 (D.D.C. 2008) (pulling the trigger of a gun to the head was "[a]nother form of torture"); Cannon v. Burge, 2006 WL 273544 (N.D. Ill. 2006) ("forms of torture" included "mock executions by placing a gun in his mouth and pulling the trigger"); In re Estate of Marcos Human Rights Litigation, 910 F. Supp. at 1463 (Russian roulette during interrogation is torture); State v. Hall, 8 S.W.3d 593, 601 (Tenn. 1999) (regarding "threats to kill," "the anticipation of physical harm to one's self or a loved one constitutes mental torture"); PAUST, supra note 1, at 13, 16, 154 n.105, 158 n.122; U.S. Dep't of State, 1999 Country Reports on Human Rights Practices, supra note 69, Iraq ("torture" included "threats to rape or otherwise harm family members and relatives"); id. 2004 Report, Turkey (methods of torture included "stripping and blindfolding, threats to detainees or family members"); infra notes 72, 83. 18 U.S.C. \& 2340(2)(C)-(D) notes that these types of threat are torture if they cause prolonged mental harm, but international law does not require that the harm be prolonged. See infra note 107. If family members were detained, however short, in connection with such threats, the conduct would also implicate the separate crime of hostage-taking, which is a grave breach of the Geneva Civilian Convention. GC, supra note 27, arts. 3(1)(b), 34, 147. It is also a crime outside the context of an armed conflict under customary and treaty-based law and there is a treaty obligation to initiate prosecution or extradite "without exception whatsoever." International Convention Against the Taking of Hostages, arts. 1, 8, Dec. 17, 1979, 1316 U.N.T.S. 205; see also 18 U.S.C. § 1203 (2000); S.C. Res. 579, थ 1, U.N. Doc. A/RES/579 (Dec. 18, 1985), ("Condemns unequivocally all acts of hostage-taking and abduction"); U.S. Diplomatic and Consular Staff in Tehran Case (United States v. Iran), 1980 I.C.J. 3 (May 24); United States v. Yunis, 681 F. Supp. 896 (D.D.C. 1988).

72 See, e.g., In re Estate of Ferdinand E. Marcos Human Rights Litig., 910 F. Supp. at 1463 ("forms of torture" include "[f]orcing a detainee while wet and naked to sit before an air conditioner often while sitting on a block of ice"); PAUST, supra note 1, at 28, 178 n.15, 255 nn.86-87; Nowak, supra note 69, at 838; Ross \& Esposito, supra note 69; Woodward, supra note 70; infra note 83. See also Choezom v. Mukasey, 2008 WL 4898685 (2d Cir. 2008) (U.S. State Department report noted Chinese "torture" of Tibetans by "exposure to cold"); Lhanzom v. Gonzales, 430 F.3d 833, 848 (7th Cir. 2005) (same); Rasul v. Rumsfeld, 414 F. Supp.2d at 27 (quoted supra note 70); Acree v. Republic of Iraq, 271 F. Supp.2d 179, 218 (D.D.C. 2003) (Saddam Hussein's "agents of torture" used "excruciating physical and mental torture" on U.S. pows, including "mock executions, threats of death, intense fear, .... severe sleep deprivation, .... intense cold"); United States ex rel. De Creti v. Wilson, 967 F. Supp. 303, 305 (N.D. Ill. 1997) (putting a baby into a freezer is torture and can 
Paust: The Absolute Prohibition of Torture and Necessary and Appropriate

2009]

to these and other unlawful interrogation tactics authorized by the Bush Administration, the Committee Against Torture declared in 2006 that the United States

should rescind any interrogation technique, including methods involving sexual humiliation, 'water boarding,' 'short shackling' [e.g., shackling a detainee to a hook in the floor], and using dogs to induce fear, that constitute torture, cruel, inhuman or degrading treatment or punishment, in all places of detention under its de facto effective control, in order to comply with its obligations under the Convention. ${ }^{73}$

support murder conviction even though death by "hypothermia or suffocation" would take time); State v. Piper, 709 N.W.2d at 799 (quoted supra note 69); In re Termination of Parental Rights to Samuel J.R., 249 Wis.2d 491, 639 N.W.2d 225 (2001) ("torture inflicted" by "placing a child in a dog cage in a cold, unheated basement and throwing a child out of the house without any shoes or clothes on a cold night"); Gutierrez v. State, $112 \mathrm{Nev}$. 788, 792, 920 P.2d 987, 990 (1996) ("clearly sadistic acts of torture: subjecting her to freezing cold" showers); Commonwealth v. Rochon, 398 Pa. Super. 494, 581 A.2d 239 (Pa. Super. 1990) ("repeatedly immersed the little boy in water ... did not stop this torture until her victim became cyanotic and turned purple from cold"); Lopez v. State, $105 \mathrm{Nev}$. 68, 71, 769 P.2d 1276, 1279 (Nev. 1989) (torture included leaving a child in a "bathtub filled with cold water for two hours"); State v. Walls, 744 S.W.2d 791, 800 (Mo. 1988) (torture occurred where victim was beaten and locked "in a freezer to slowly suffer death by either suffocation or hypothermia"); Anderson v. State, 466 N.E.2d 27, 33 (Ind. 1984) ("evidence of torture" involved "body wounds and testimony of repeatedly dousing the boy in cold water"); State v. Smith, 305 N.C. 691, 711, 292 S.E.2d 264, 276-77 (N.C. 1982) ("victim suffered agonizing and humiliating torture" by being raped and "cruelly mocked ... as she stood naked in the cold"); Elci and Others v. Turkey, [2003] ECHR 23145/93, para. 646 (Nov. 13, 2003) (being "stripped naked and hosed down with freezing cold water" and being "threatened with death" "must... be regarded as constituting torture"); Edith Rose Gardner, Coerced Confessions of Prisoners of War, 24 GEO. WASH. L. REV. 528, 534-35 (1955-56) (North Korean's used "severe" methods, including cases where prisoners "were kept standing ... in ... winter cold for hours" and where some "were forced to stand on the frozen Yala River, barefooted, their feet drenched with water which instantly froze fast to the ice, and to remain there to 'reflect.'"); Gabor Rona, Legal Issues in the "War on Terrorism - Reflecting on the Conversation Between Silja N.U. Voneky and John Bellinger, 9 GERMAN L.J. 711, 719 nn.30, 32 (2008); U.S. Dep't of State, 1999 Country Reports on Human Rights Practices, supra note 69, Egypt ("torture methods" included being "stripped, ... doused with ... cold water, ... forced to stand outdoors in cold weather" [this last method, being forced to stand outdoors in the cold, is not in the 2002 or 2003 report); id., Turkey (methods of torture include "stripping and blindfolding[] and exposure to extreme cold or high-pressure cold water hoses"); Woodward, supra note 70; infra note 83. A variation of the "cold cell" involves stripping a person naked, placing the person in a cold room, and dousing the person with water in order to produce hypothermia that can turn the body blue and produce violent shaking and even death.

73 CAT Report, supra note 22, ๆ 24. See also International Committee of the Red Cross, 
Valparaiso University Law Review, Vol. 43, N 0. 4 [2009], Art. 1

Although the intentional use of sexual violence and rape as tactics are recognizably torture, ${ }^{74}$ some forms of sexual humiliation that were authorized and used might not have constituted severe pain or suffering. Nonetheless, they can be manifestly inhumane or degrading and, therefore, equally unlawful. Previously, the Committee condemned the following tactics as either torture or cruel, inhuman or degrading treatment proscribed by the Convention: (1) restraining in very painful conditions, (2) hooding under special conditions, (3) sounding of loud music for prolonged periods, (4) sleep deprivation for prolonged periods, (5) threats, including death threats, (6) violent shaking, and (7) using cold air to chill. ${ }^{75}$

ICRC Report on the Treatment of Fourteen "High Value Detainees" in CIA Custody 8-9, 26 (Feb. 2007), available at http://pegc.us/archive/Organizations/ICRC_rpt_hvd_20070214.pdf (alleged unlawful tactics included: suffocation by water, prolonged stress standing position, beatings by use of a collar, beating and kicking, confinement in a box, prolonged nudity, sleep deprivation, exposure to cold temperature, prolonged shackling, threats of illtreatment, forced shaving, deprivation/restricted provision of solid food.

This regime was clearly designed to undermine human dignity and to create a sense of futility by inducing, in many cases, severe physical and mental pain and suffering... resulting in exhaustion, depersonalization and dehumanization. The allegations of illtreatment of the detainees indicate that, in many cases, the illtreatment ... either singly or in combination, constituted torture. In addition, many ... constituted cruel, inhuman or degrading treatment.

In Mehinovic v. Vuckovic, 198 F. Supp. 2d 1322, 1347-49 (N.D. Ga. 2002), the court recognized that "[c]ruel, inhuman, or degrading treatment is a discrete and wellrecognized violation of customary international law and is, therefore, a separate ground for liability," adding, "cruel, inhuman, or degrading treatment includes acts which inflict mental or physical suffering, anguish, humiliation, fear and debasement, which do not rise to the level of 'torture' and that being "forced to observe the suffering of their friends and neighbors... [is] another form of inhumane and degrading treatment[.]" See also Rome Statute of the ICC, supra note 21, arts. 8(b)(xxi), (c)(ii) ("humiliating and degrading treatment" are "outrages upon personal dignity" and are war crimes).

74 See, e.g., Farmer v. Brennan, 511 U.S. 825, 852, 854 (1994) (Blackmun, J., concurring); Doe I v. Unocal Corp., 395 F.3d 932, 945 (9th Cir. 2002); Zubeda v. Ashcroft, 333 F.3d 463, 472 (3d Cir. 2003) (“[r]ape can constitute torture”); Kadic v. Karadzic, 70 F.3d 232, 242 (2d Cir. 1995); In re Extradition of Suarez-Mason, 694 F. Supp. 676, 682 (N.D. Cal. 1988); Prosecutor v. Kunarac, Kovac \& Vukovic, IT-96-23 \& IT-96-23/1A, Judgement 9 137, 15051, 153 (June 12, 2002); Prosecutor v. Musema, ICTR-96-13-T, Transcript ๆ 222 (Jan. 27, 2000); Torture Victims Relief Act, 22 U.S.C. § 2152 note (torture includes "rape and other forms of sexual violence"); HENCKAERTS \& DOSWALD-BECK, supra note 21, at 318 \& n.99; Diane Marie Amann, International Decisions: Prosecutor v. Akayesu, 93 AM. J. INT'L L. 195, 196-97 (1999); Evelyn Mary Aswad, Torture by Means of Rape, 84 GEO. L.J. 1913, 1915-16 (1996); Beth Stephens, Humanitarian Law and Gender Violence: An End to Centuries of Neglect?, 3 HOFSTRA L. \& POL'Y SYMP. 87, 95-96 (1999); see also Prosecutor v. Delalic, ICTY96-21-7, Judgement 9 475-97 (Nov. 16, 1998); PAUST, BASSIOUNI, ET AL., supra note 26, at 693, 748.

75 Concluding Observations of the Committee against Torture: Israel, 18th Sess., ๆ 256- 
Paust: The Absolute Prohibition of Torture and Necessary and Appropriate

2009]

Many of these illegal tactics, including water-boarding and the "cold cell," were addressed and expressly and/or tacitly approved during several meetings of the National Security Council's Principals Committee in the White House during 2002 and 2003 that were attended by Dick Cheney, his lawyer David Addington, Condoleezza Rice, Donald Rumsfeld, George Tenet, John Ashcroft, and others who facilitated their approval and use, including John Yoo. ${ }^{76}$ With a typical

57 U.N. Doc. A/52/44 (Sept. 5, 1997). Concerning torture by sleep deprivation, see also Acree v. Republic of Iraq, 271 F. Supp.2d at 218 (quoted supra note 72); Shepherd v. Ault, 982 F. Supp. 643, 648 (N.D. Ill. 1997) ("[T]he effectiveness of sleep deprivation as a tool of torture has long been recognized." (citing Reck v. Pate, 367 U.S. 433 (1961); Ashcraft v. Tennessee, 322 U.S. 143, 151 (1944)); Rounds v. State, 106 S.W.2d 212, 213 (Tenn. 1937) ("To deprive a human of sleep for four days and nights is a form of torture not less severe than physical violence.") (citing Ziang Sun Wan v. United States, 266 U.S. 1 (1924)).

76 Jan Crawford Greenburg, Howard L. Rosenberg \& Ariane de Vogue, Bush Aware of Advisers' Interrogation Talks, ABC News, Apr. 11, 2008 http://abcnews.go.com/print?id= 4635175 (last visited Feb. 9, 2009) (adding, "the most senior Bush administration officials repeatedly discussed and approved specific details," and "meetings... were typically attended by most of the principals or their deputies," and "[s]ources said that at each discussion, all the Principals present approved"). The meetings were often held in the White House situation room. Id. See also Lara Jakes Jordan, Cheney Led Approvals of Harsh Interrogations, STAR-LEDGER (Newark, NJ), Apr. 11, 2008 at 1; Mark Mazzetti, Top U.S. Officials Debated CIA Methods, INT'L HERALD TRIB., Sept. 25, 2008, available at http://www.iht.com/articles/2008/09/25/america/cia.php (last visited Feb. 9, 2009) (adding that John Bellinger has stated that John Yoo issued oral guidance concerning interrogation tactics to the CIA during such meetings); Greg Miller, Cheney Says He Had Key Role in Interrogation Methods, BALT. SuN, Dec. 16, 2008, at 14A; Joby Warrick, Top Officials Knew in 2002 of Harsh Interrogations, WASH. POST, Sept. 25, 2008, at A7; Jan Crawford Greenburg, Howard L. Rosenberg \& Ariane de Vogue, Sources: Top Bush Advisors Approved 'Enhanced Interrogation' - Detailed Discussions Were Held About Techniques to Use on al Qaeda Suspects, ABC News, Apr. 9, 2008 available at http://abcnews.go.com/TheLaw/ LawPolitics/story?id=4583256\&page=1 (those who participated "approved," a "handful of top advisers signed off on," discussions of techniques "were so detailed" that some "were almost choreographed," and Tenet "regularly sought confirmation"); Lara Jakes Jordan \& Pamela Hess, Cheney, Others OK'd Harsh Interrogations, Apr. 11, 2008, http://abcnews.go. $\mathrm{com} /$ politics/wirestory?id=4631535; Matthew Lee, Rice Defends Post 9/11 Interrogation Techniques, AP NEWs, May 22, 2008, http://ap.google.com/article/ALeqM5jYsZfE9RBbjOv-ed37E9_23gLdQD90R5MD00; Ashcroft Involved With Torture Memos, Bush Administration Lawyers, June 27, 2008, available at http://jurist.law.pitt.edu/paperchase/ 2008/06/ashcroft-involved-with-torture-memos.php (last visited Feb. 9, 2009); White House Memos to CIA Approved Waterboarding : Washington Post, Oct. 15, 2008, available at http://jurist.law.pitt.edu/paperchase/2008/10/white-house-memos-to-cia-approved.php (last visited Feb. 9, 2009); Report, Senate Armed Services Committee Inquiry Into the Treatment of Detainees in U.S. Custody, (Dec. 20, 2008) [hereinafter Senate ASC Report], http://armed-services.senate.gov/Publications/EXEC\%20SUMMARY-CONCLUSIONS_ For\%20Release_12\%20December\%202008.pdf; PAUST, supra note 1, at 28, 30, 150-51 n.89 (regarding White House meetings chaired by Alberto Gonzales, with William Haynes and David Addington in attendance, discussing and approving or finding "acceptable" specific interrogation tactics such as water-boarding), 152 n.96 (regarding Porter Goss on water- 
Valparaiso University Law Review, Vol. 43, N0. 4 [2009], Art. 1

boarding), $161 \mathrm{n} .138$ ("simulated drowning and the withholding of pain medication[] were authorized for the CIA at White House meetings" chaired by Gonzales), 175 nn.11-12 (regarding roles of Cheney and Addington), 179 n.18 (regarding the role of Gonzales), 179 n.19 (Presidential Finding in 2002 signed by President Bush, National Security Adviser Rice, and Attorney General Ashcroft approved water-boarding and other unlawful coercive interrogation tactics), 181 n.28 (regarding the role of Gonzales); JOHN YOO, WAR BY OTHeR MeAns 30-31 (Atlantic Monthly Press 2006). Starting in December 2001,

Senior lawyers from the attorney general's office, the White House counsel's office, the Departments of State and Defense, and the NSC met.... This group of lawyers would meet repeatedly over the next months to develop policy of the war on terrorism. We certainly did not all agree.... Meetings were usually chaired by Alberto Gonzales.... At meetings, his deputy, Timothy Flanigan, usually played the role of inquisitor....

Id. [O]ften at the meetings were William Howard Taft IV, John Bellinger, Jim Haynes, David Addington and "Bellinger often shared Taft's accommodating attitude toward international law[.]" Id. at 32-33. In mid-January 2002, "the lawyers met again in the White House situation room.... Consensus eluded the group," but Gonzales would later summarize the positions for the President. Id. at 39. Scott Shane, David Johnston \& James Risen, Secret U.S. Endorsement of Severe Interrogations, N.Y. TIMES, Oct. 4, 2007, at 1 (Attorney General Gonzales approved a memo written by Steven G. Bradbury attempting to justify coercive CIA tactics, including "simulated drowning and frigid temperatures" and their use for "combined effects;" Deputy Attorney General James B. Comey warned Gonzales that he should not approve, but Gonzales "made clear that the White House was adamant about it, and that he would do nothing to resist;" and some officials warned "that no reasonable interpretation of 'cruel, inhuman or degrading' would permit" certain CIA methods, including water-boarding); Barton Gellman \& Jo Becker, Angler: The Cheney Vice Presidency, June 24, 2007, at 1 http://blog.washingtonpost.com/cheney/chapters/ chapter_1/ (last visited Feb. 9, 2009); (general roles of Cheney, Addington, Flanigan, and Gonzales in denying Geneva law protections to detainees), infra notes 77-80, 86, 89-96, 99102. ABC News, supra. Then Attorney General Ashcroft provided a trenchant warning at one of the meetings: "Why are we talking about this in the White House? History will not judge this kindly." Indeed, how could one whose heart had not grown cold even sit through explanations of water-boarding, the cold cell, and use of dogs to terrorize naked detainees without realizing that such methods are, at a minimum, inhumane and an assault on human dignity?

Responses of Condoleezza Rice, Sept. 12, 2008, in Opening Statement by Senator Carl Levin, Senate Armed Services Committee Hearing on the Authorization of SERE Techniques for Interrogations in Iraq: Part II of the Committee's Inquiry into the Treatment of Detainees in U.S. Custody (Sept. 25, 2008), TAB 3, at 3-5, 7, http://levin.senate.gov/ newsroom/supporting/2008/SASC.documents.092508.pdf. In written responses on September 12, 2008 to questions from Senator Carl Levin, Secretary Rice stated that "CIA's proposed program was ... reviewed by the NSC Principals," she "was present in meetings at which DOJ lawyers provided legal advice about the CIA program" and "that John Yoo provided advice at several of these meetings," she "asked the Attorney General personally to review the legal guidance prepared by OLC [DOJ]," she understands that DOJ "was providing advice to CIA, and that this advice was being coordinated by Counsel to the President Alberto Gonzales," and her legal adviser John Bellinger "advised me on a regular basis regarding concerns and issues relating to DOD detention policies and practices at Guantanamo." Id. Senator Levin's statement is available at http://levin.senate.gov/ newsroom/release.cfm?id=303575. Written responses of John Bellinger to Senator Levin 
smug defiance, Cheney admitted that "he was directly involved in approving severe interrogation methods... including...'waterboarding" and that he was "involved in helping get the process cleared."77 With respect to the configurative contributions of his team, President Bush was quoted as stating “yes, I'm aware our national security team met on this issue. And I approved."78

stated that "[a] number of individuals who were present at meetings I attended on the CIA program, or the legal guidance thereon, asked questions or expressed concerns about these issues," and "I was present at several meetings at which OLC attorneys provided oral advice regarding interrogation techniques proposed to be used by CIA," and "I recall that ... John Yoo provided legal guidance in some of the meetings," thus "I raised ... concerns [upon hearing about tactics used at GTMO] on several occasions with DOD officials and was told that the allegations were being investigated by the Naval Criminal Investigative Service." Id. TAB 4, at 3-5, 8. Merely raising concerns and asking for further inquiry might not be enough to avoid responsibility if one continued to attend such meetings; knew that tactics such as water-boarding, the cold cell, or the use of dogs against naked detainees to instill intense fear continued; and did not resign. See, e.g., Trial of Koiso, supra note 43; see also supra note 40. Again, it is difficult to believe that anyone who attended such meetings would not realize that such tactics are, at a minimum, inhumane.

77 See Miller, supra note 76, adding that when "[a]sked whether he still believes it was appropriate to use the waterboarding method ..., Cheney said: 'I do.'" Concerning the role of Cheney, see also PAUST, supra note 1, at 12, 27-28, 30, 150 n.89, 153-54 n.97, 175-7 nn.9-10, 13-14; Demetri Sevastopulo, Cheney Endorses Simulated Drowning, MSNBC, Oct. 26, 2006, http://www.msn.com/id/15433467; Scott Hennen interview with Vice President Richard Cheney, in Washington, D.C. (Oct. 24, 2006) http:/ / www.whitehouse.gov/news/ releases/2006/10/20061024-7.html (water-boarding has "been a very important tool that we've had to be able to" use); supra note 76.

78 ABC News Apr. 11, 2008, supra note 76. See also Shane, Johnston \& Risen, supra note 76 (in July 2006, President Bush signed a new executive order to further his program of "enhanced" interrogation and secret detention); Randall Mikkelsen, CIA Detention Program Remains Active: U.S. Official, ReUTERS News, Oct. 4, 2007; Dan Eggen, White House Defends CIA's Use of Waterboarding in Interrogations, WASH. POST, Feb. 7, 2008, at A3 (White House spokesman Tony Fratto said water-boarding is legal and can be authorized and that "every enhanced technique that has been used by the CIA for this program was brought to the Department of Justice, and they made a determination"; "CIA Director Michael V. Hayden confirmed ... that the agency had used waterboarding[.]"); Interview of President George W. Bush by Brit Hume, Fox News Sunday (Jan. 7, 2009) http://www.youtube.com/ watch?v=gnpZgMlw9-o (last visited Feb 9, 2009) (Bush admits that he approved the use of such "techniques" or "tools" and had authorized their use on at least "one such person who gave us information," Khalid Sheik Muhammad); President George W. Bush, radio address, Mar. 8, 2008 http://www.whitehouse.gov/news/releases/2008/03/20080308. $\mathrm{html}$ (concerning his veto of an Intelligence Authorization Act of 2008 that would have required CIA personnel to follow a military manual that prohibits water-boarding, sensory deprivation, hypothermia, and denial of food, water or medical care, Bush stated that the legislation "would take away one of the most valuable tools in the war on terror-the CIA program to detain and question" - and take away "specialized interrogation procedures to question" and "would eliminate all the alternative procedures we've developed to question" detainees). 
Valparaiso University Law Review, Vol. 43, N 0. 4 [2009], Art. 1

During President Bush's admitted "program" of "tough" interrogation and secret detention or forced disappearance, ${ }^{79}$ and as part of the well-documented "common, unifying" plan to deny Geneva law protections and to use and attempt to justify serial and cascading criminality in the form of "coercive interrogation," 80 the Administration used shifting definitions of "torture" as if the manifest illegality of its approved interrogation tactics could be defined away. The definitions did not reflect well-known definitions and criteria used in customary and treaty-based international law, ${ }^{81}$ or, at times, those used by the U.S. Executive in its Department of State Country Reports on Human Rights Practices for a number of years and by judges in many U.S. federal and state court cases addressing the types of treatment authorized by President Bush and his entourage, ${ }^{82}$ including several cases addressing

79 See, e.g., PAUST, BEYOND THE LAW, supra note 1, at 29, 179-80 n.22; supra notes 21-22. Concerning Bush admissions, authorizations, directives, and findings, see, e.g., $i d$. at $x, 7-8$, 17, 26, 28-30, 32, 35, 145-47, 176, 179-80; Majority Staff Report, H.R. COMM. ON THE JUDICIARY, REINING IN THE IMPERIAL PRESIDENCY: LESSONS AND RECOMMENDATIONS Relating to the Presidency of GeORge W. Bush, at 136 Jan. 13, 2009 [hereinafter House Comm. Report] ("[I]n Secretary Powell's view, Mr. Bush was 'complicit' in these abuses.") available at http://judiciary.house.gov/hearings/printers/110th/IPres090113.pdf; supra note 78; infra notes 101-02.

80 See, e.g., House Comm. Report, supra note 79, at 110-46; PAUST, BEYOND THE LAW, supra note 1, at 27-30, 32; JANE MAYER, THE DARK SIDE: THE INSIDE STORY OF HOW THE WAR ON TERROR TURNED INTO A WAR ON AMERICAN IDEALS 150 (Doubleday 2008) (noting an early 2002 meeting of Yoo, Gonzales, Addington, Flanigan, and Haynes discussing "what sorts of pain" to inflict), 185 (noting conflicts between Addington and Bellinger), 198-99 (noting that Addington, Gonzales, Haynes, Goldsmith, and others had flown to Guantanamo in September 2002 to discuss and observe use of SERE [Survival Evasion Resistance and Escape] tactics on detainees who were still held in secret detention or forced disappearance), 304, 307, 311-12 (noting the facilitating role of Gonzales) (Doubleday 2008); YoO, supra note 76, at ix, 30, 35, 39-40, 43, 171-72, 177-78, 190-92, 200, 202; UN Torture Investigator Calls on Obama to Charge Bush for Guantanamo Abuses, JURIST, Jan. 21, 2009, available at http://jurist.law.pitt.edu/paperchase/2009/01/un-torture-investigator-callson-obama.php; supra notes 76-78; infra notes 84-102 and accompanying text. John Yoo wrote that he had also flown with other lawyers to Guantanamo in early January 2002. See YoO, supra note 76, at 18, 38-39, 44. Those lawyers knew that persons transferred to Guantanamo were held in secret detention because their names were not released. Such constitutes a form of forced disappearance, a crime against humanity that during an armed conflict is also a war crime. See supra note 21.

81 See, e.g., PAUST, BEYOND THE LAW, supra note 1, at 11, 150-51 nn.89-90 (discussing the Administration's attempt to limit or redefine "torture" in order to permit aggressive and painful interrogation techniques); supra notes 62 (providing typical definitions of torture), 69 (discussing various techniques that have historically been categorized as "torture"), $72-$ 74 (providing more standards and specific examples of "torture"); infra notes 85 (analyzing the Bybee torture memo's ability to provide a defense to alleged acts of "torture"), 107 (recognizing the pitfalls of the justice system's ability to prosecute acts of "torture" and the need to ensure that all acts of "torture" are criminal offenses).

82 See supra notes 69 (describing specific techniques that have traditionally been called 
the prohibition of "cruel" treatment and torture under the Eighth Amendment to the U.S. Constitution. ${ }^{83}$ These cases and Country Reports on Human Rights could have been easily discovered through use of computer-assisted research, thus demonstrating that several writers of memoranda did not attempt to provide independent, careful, and professional legal advice.

In particular, one memorandum (often-called the "Bybee torture memo"), ${ }^{84}$ completed in August 2002 by John Yoo and Jay Bybee, set forth what had become the Administration's preferred but patently improper standard regarding "torture." According to the Bybee memo,

“torture"), 72.

83 More generally, the Supreme Court has recognized the impermissibility of "coercive cruelty." Weems v. United States, 217 U.S. 349, 373 (1910). U.S. cases have also provided information recognizing what types of conduct can amount to cruel treatment under the Eighth Amendment. See, e.g., Hudson v. McMillian, 503 U.S. 1, 14, 17 (1992) (Blackmun, J., concurring) (finding that "shocking them with electric currents, asphyxiating them short of death, intentionally exposing them to undue heat or cold," and inflicti[ng] ... "psychological pain" is cruel treatment); Wilson v. Seiter, 501 U.S. 294, 304 (1991) (involving a combination of deprivation of food and warmth, "for example, a low cell temperature at night combined with a failure to issue blankets." Relevant mens rea can involve "wanton" conduct or "deliberate indifference[.]"); Estelle v. Gamble, 429 U.S. 97, 104 (1976) ("deliberate indifference to serious medical needs of prisoners constitutes the 'unnecessary and wanton infliction of pain[]'”); Brooks v. Florida, 389 U.S. 413, 414-15 (1967) (deprivation of adequate food and detention naked in a small cell was in context "a shocking display of barbarism"); Beecher v. Alabama, 389 U.S. 35, 36, 38 (1967) ("gross coercion[]" existed when an officer pressed a gun to the face and stated "'[i]f you don't tell the truth I am going to kill you[]" and thereafter another officer fired a rifle nearby); Robinson, 370 U.S. at 669 (Douglas, J., concurring) ("water cures" are "terror"); United States v. Rojas Tapia, 466 F.3d 1, 4 (1st Cir. 2006) ("physically coercive punishment, such as an unreasonable deprivation of food or sleep[]" obviates voluntariness of a confession); Dixon v. Godinez, 114 F.3d 640, 642 (7th Cir. 1997) (subjection to cold); Littlewind v. Rayl, 33 F.3d 985, 986 (8th Cir. 1994) (finding that the plaintiff had been restrained naked for seven hours, denied clothing for six days, denied a blanket for two days, restrained seven days in leg irons and handcuffs, and tied to a bed for eight hours); Northington v. Jackson, 973 F.2d 1518, 1523 (10th Cir. 1992) (describing an incident where an officer threatened to kill a suspect by pointing a gun to his head); Wright v. McMann, 387 F.2d 519, 526 (2d Cir. 1967) (finding that solitary confinement conditions in a "strip cell" (where a prisoner is nude and exposed to bitter cold) is cruel and "serve[s] to destroy completely the spirit and undermine the sanity of the prisoner[]") (internal citations omitted); Scarver v. Litscher, 371 F. Supp. 2d 986, 993 (W.D. Wis. 2005) (stripping a person naked and placing him in a cold cell without a mattress, blankets, etc.); Ferola v. Moran, 622 F. Supp. 814, 821 (D.R.I. 1985) (restraint so as to deny access to a bathroom for fourteen hours); Hancock v. Avery, $301 \mathrm{~F}$. Supp. 786, 789 (M.D. Tenn. 1969) (forcing persons to strip nude and sleep on cement floors with no means to maintain personal cleanliness); Al Ghashiyah v. McCaughtry, 602 N.W.2d 307, 311, 316 (Wis. Ct. App. 1999) (finding that strip searches employed for the purpose of intimidating a person or humiliating or harassing are not legal.). See also Hudson, 503 U.S. at 26 (quoted supra note 69).

84 See PAUST, BEYOND THE LAW, supra note 1, at 11, 150 n.89. 
Valparaiso University Law Review, Vol. 43, N0. 4 [2009], Art. 1

"torture" should involve far more than the widely known treaty-based and customary international legal test of "severe" physical or mental pain or suffering, and the test set forth in 18 U.S.C. § 2340(1). According to the Bybee memo, the definition of "severe" must be the "equivalent [of] the pain that would be associated with serious physical injury so sever [sic] that death, organ failure, or permanent damage resulting in a loss of a significant body function will likely result[.]" $]^{\prime \prime 5}$ Because the

85 Id. at 151 n.90. Some news media have referred to the Bybee torture memo as the "Golden Shield[,]" as if it can shield those who planned, authorized, ordered, abetted, or perpetrated torture, cruel, inhumane or degrading treatment from criminal prosecution. See, e.g., Greenburg, et al., supra note 76. However, the shield is made of fool's gold and is full of holes. For example, orders or authorizations to engage in interrogation tactics that will manifestly produce what the community will judge to be torture, cruel, inhumane, or degrading treatment are orders or authorizations to engage in conduct that is manifestly illegal whether or not the criminal accused knows that the conduct is illegal or knows that the conduct is torture, cruel, inhumane, or degrading. Manifestly unlawful orders or authorizations are not a defense. See, e.g., PAUST, et al., supra note 26, at 100-14; Rome Statute of the ICC, supra note 21, at 19, art. 33(1) (stating that an order does not relieve the recipient of responsibility unless "(b) [t] he person did not know that the order was unlawful; and (c) [t] he order was not manifestly unlawful[]"); see also id. at 19, art. 33(2) ("orders to commit... crimes against humanity are manifestly unlawful[]" per se). Thus, as a matter of law, an order to engage in forced disappearance or secret detention as an admitted part of the Bush program is not a defense. See also FM 27-10, supra note 28, at 182, - 509(a) (an order does not constitute a defense for the recipient "unless he did not know and could not reasonably have been expected to know that the act ordered was unlawful"); CAT, supra note 20, at 114, art. 2(3) ("An order ... may not be invoked as a justification of torture."); PAUST, BEYOND THE LAW, supra note 1, at 37-38, 111-12, 155-56 n.113, 170 n.193, 179 n.21, 261 n.115, 286-87 n.90; United States v. Von Leeb and Others (The High Command Case (1948)), 15 INT'L L. REPS. 376 (1949) (Hitler's directives "had the force and effect of law[,]" but to recognize as a defense to international crimes that a defendant acted pursuant to the order of his government or of a superior "would be to recognize an absurdity[;]" international law "must... take precedence over National Law or directives issued by any national governmental authority[;]" and "[a] directive to violate International Criminal . . Law is therefore void and can afford no protection to one who violates such law in reliance on such a directive...."). The ploy "I did not know that water-boarding was unlawful or torture" will not work, since water-boarding is manifestly unlawful and torture (see supra note 69); and if it is not torture, it is cruel, and if it is not cruel, it is inhumane and, therefore, it is necessarily unlawful under common Article 3 of the Geneva Conventions, Articles 1 and 16 of the CAT, Article 7 of the ICCPR, customary international law reflected in the above, and so forth. Although this writing focuses mainly on torture, a primary prohibition is the outlawry of inhumane treatment. See also supra notes 2, 73 (discussing the fact that inhumane treatment in any circumstance is unlawful regardless of whether it rises to the level of "torture"). Furthermore, the Bybee memo was written after specific tactics had been used and, therefore, was inoperative as any putative "shield" regarding prior conduct because it could not have been honestly relied on. Quite clearly, the mere fact that a particular tactic was approved in an Executive memo is not a defense, and if Attorney General Holder is going to uphold his duty to prosecute crime, he cannot consider that a memo provides immunity.

Additionally, several high level officials were warned or on notice of legal 
Paust: The Absolute Prohibition of Torture and Necessary and Appropriate

memo was written after several of the White House meetings during which an inner circle (and John Yoo) had discussed and approved or facilitated use of specific interrogation tactics, ${ }^{86}$ and was created

improprieties regarding denial of Geneva protections, secret detention, and use of coercive tactics. See, e.g., PAUST, supra note 1, at 5-8, 14-17, 19, 50-51, 162-63 n.143, 172-73 n.1, 176 nn.11-12, 188 n.45; Senate ASC Report, supra note 76, at xviii-xxi; Jane Mayer, The Memo: How an Internal Effort to Ban the Abuse and Torture of Detainees Was Thwarted, THE NEW YORKER, (Feb. 27, 2006), available at http://www.newyorker.com/archive/2006/02/27/ 060227fa_fact (regarding warnings by Alberto Mora and others); Shane et al., supra note 76 (reporting on the Justice Department's secret endorsement of the harshest interrogation techniques ever used by the CIA); supra notes 22, 73 (discussing U.N. Committee Against Torture reports condemning cruel treatment that does not rise to the level of torture). Some of the International Committee of the Red Cross warnings of widespread and intentional unlawful treatment had even become public, which usually occurs after warnings to government officials and quiet diplomacy have failed. See, e.g., PAUST, supra note 1, at 17, 19, 162 n.143, 163 n.145, 268 n.15 (discussing various Red Cross warnings). Criminal conduct was also widely reported for several years by various media and nongovernmental organizations, such as Amnesty International, Human Rights Watch, Human Rights First, the American Bar Association, the ACLU, and the Center for Constitutional Rights. At least by 2004, public constructive notice was rampant. For many years before and during the Bush Administration, the Executive's own Country Reports on Human Rights Practices had also listed several relevant tactics as torture. See supra notes 69, 71-72. By 2005, public condemnation also occurred by the Council of Europe Parliamentary Assembly. See supra note 21 (discussing the various groups that condemned the Bush Administration's actions). In 2006, in the face of known illegalities of the Bush Administration, a rare resolution of the American Society of International Law was created because of the tireless professional efforts of Professor Ben Davis, reaffirming what every professional international lawyer had known, that "[t]orture and cruel, inhuman, or degrading treatment of any person ... are prohibited by international law from which no derogation is permitted[,]" among other points. See Resolution Adopted, THE AMERICAN SOCIETY OF INTERNATIONAL LAW, Mar. 30, 2006, available at http://www.asil.org/events/ amo6/resolutions.html. The U.S. Congress had made this point earlier in October 2004. See PAUST, BEYOND THE LAW, supra note 1, at 177 n.13 (describing that a year earlier the full Congress declared that torture or cruel treatment of prisoners held in the custody of the United States was prohibited).

86 See supra note 76; see also Senate ASC Report, supra note 76, at xv-xvi (Bellinger "said that he was present in meetings [of the NSC's Principals Committee] 'at which SERE training was discussed.'" Two Bybee memos were written "after consultation with senior Administration attorneys, including" Gonzales and Addington [one memo is public and known as the Bybee torture memo. Another memo had addressed specific interrogation tactics and has not been declassified]; "[b]efore drafting the opinions, Mr. Yoo, ... met with Alberto Gonzales" and Addington "to discuss the subjects he intended to address in the opinions[]"; Bybee "saw an assessment of the psychological effects of military resistance training [the SERE program] in July 2002 in meetings in his office with John Yoo ... [and] Bybee said that he used that assessment to inform the August 1, 2002 OLC legal opinion" on tactics. "Bybee also recalled discussing detainee interrogations in a meeting with Attorney General John Ashcroft and John Yoo in late July 2002, prior to" creation of the opinions). John Yoo has admitted that an inner circle devised a "common, unifying" plan to deny Geneva law protections and to authorize and facilitate use of "coercive interrogation" (which violates international law whether or not particular tactics are 
expressly to deal with "the conduct of interrogations outside of the United States and possible defenses that [allegedly] would negate any claim that certain interrogation methods [already approved] violate" a particular federal statute, ${ }^{87}$ it is obvious that the memo was not written for independent professional legal advice, but to provide possible cover for tactics already approved and to facilitate their use in the future. Moreover, because the memo writers had refused to use the widely known test with respect to torture, the Bybee memo was facially devoid of legal propriety and blatantly facilitated the use of criminal interrogation tactics. The memo had also made the patently erroneous claim that, as a matter of law, "necessity and self-defense could justify interrogation methods needed to elicit information." 88

Criticism of the manifestly erroneous memo grew so widespread in the U.S. and abroad that the memo was eventually withdrawn and replaced by a 2004 memo that is still classified; however, criticism continued to demonstrate that the Bush Administration's definition of torture remained unacceptable and that unlawful tactics being used for interrogation had not been withdrawn. There was actually a second August 2002 Bybee memo prepared by John Yoo that addressed specific interrogation tactics. ${ }^{89}$ It was not withdrawn until June $2004^{90}$ when the new head of OLC, Jack Goldsmith, finally decided to withdraw the opinion nearly eight months after he had learned of the secret CIA tactics for interrogation authorized in the second Bybee memo. ${ }^{91}$ For nearly eight months, Goldsmith apparently decided that he would not oppose the use of any particular tactic addressed in the memo or otherwise known to be used by the CIA. ${ }^{2}$

torture). See, e.g., PAUST, supra note 1, at 30, 181-82 nn.28-35. As Steven Kleinman noted during the 2009 Valparaiso University Law Review Symposium, those who recommended and authorized the use of SERE tactics apparently did not understand that they are unavoidably counterproductive and harm efforts to produce needed reliable intelligence.

87 See PAUST, BEYOND THE LAW, supra note 1 , at 150 n.89.

88 Id. at 11. But see supra notes 1, 9, 11, 14, 67 and accompanying text (stating that torture and unlawful treatment is definitively condemned even in the face of armed conflict and the needs of national defense).

89 See supra note 86 (describing two Bybee memos); JACK GOLDSMITH, THE TERROR PRESIDENCY: LAW AND JUdGMENT INSIDE THE BUSH ADMINISTRATION 150-51, 155 (W. W. Norton \& Co. 2007) ("in a second August 1, 2002, opinion that still remains classified, OLC applied....abstract analysis to approve particular and still-classified interrogation techniques... that underlay the CIA interrogation program[]" and "attendant CIA techniques[]").

90 GOLDSMITH, supra note 89, at 159.

91 See id. at 150-55, 159.

92 See id. Despite the fact that the second August 2002 opinion remains classified, we know that some of the illegal tactics authorized for use included water-boarding, use of dogs to create intense fear, threatening to kill detainees, the use of the cold cell, stripping 
A March 14, 2003 memo written by John Yoo for William Haynes ${ }^{93}$ (after participation in several of the White House meetings of the Principals Committee) had, in Goldsmith's words, "contained abstract and overbroad legal advice, but the actual techniques approved by the [defense] department were specific[.]"94 In December 2003, Goldsmith decided to withdraw the March 2003 Yoo memo, but he told Ashcroft and Haynes that he allowed the Department of Defense "to continue to employ the twenty-four techniques." 95

In March 2004, a draft memo penned and "circulated" by Jack Goldsmith fit perfectly within the common, unifying plan to deny Geneva protections and engage in secret detention and coercive interrogation by claiming that persons in Iraq can be transferred "to another country to facilitate interrogation[,]"96 despite the clear, absolute,

naked and hooding detainees, and sexual humiliation. See supra notes 69-73, 76-80 (discussing various tactics used to "interrogate" detainees). See also Senate ASC Report, supra note 76, at xxviii (noting that Rumsfeld's approval of Haynes's recommendation in 2002 "influenced and contributed to the use of abusive techniques, including military working dogs, forced nudity, and stress positions, in Afghanistan and Iraq[]").

93 John C. Yoo, Memorandum for William J. Haynes II, General Counsel of the Department of Defense, (Mar. 14, 2003), available at http://www.aclu.org/pdfs/safefree/yoo_army_ torture_memo.pdf.

94 GOLDSMITH, supra note 89, at 151.

95 Id. at 153, 154-55. Goldsmith was referring to Rumsfeld's twenty-four techniques. Id. at 153. Concerning these tactics, see PAUST, BEYOND THE LAW, supra note 1, at 15, 158-59 n.122; see also supra note 92 (discussing several of the illegal tactics authorized for use in the "interrogation" of detainees).

96 See PAUST, BEYOND THE Law, supra note 1, at 18, 163 n.148. See also GolDSMITH, supra note 89 , at 99-100 (reporting that Goldsmith flew to GTMO with Addington, Philbin, Rizzo, and others and that they were briefed and "witnessed an ongoing interrogation[]"), 119 ("[T]he United States could not, in my view, be bound by any customary laws of war to confer legal protections on the terrorists detained at GTMO."), 136 (stating that even after the Supreme Court rightly recognized in Hamdan, in 2006, that Common Article 3 provides a set of minimum rights "of humane treatment[,]" Goldsmith thought [without explanation] that the "Article 3 holding was legally erroneous[]"), 153 (reporting that Goldsmith, Philbin, and others decided that the twenty-four tactics that had been authorized in the April 2003 Rumsfeld memo were lawful, including "Fear Up Harsh: Significantly increasing the fear level in a detainee" [See Secretary Donald Rumsfeld, Memorandum for the Commander, US Southern Command, Apr. 16, 2003, Tab A, \#E, reprinted in KAREN J. GREENBERG \& JOSHUA L. DRATEL, THE TORTURE PAPERS 334, 335 (2005). Other tactics reportedly authorized included unlawful tactics of stripping naked and hooding for interrogation, use of dogs for interrogation, and short shacking, etc.]; MAYER, THE DARK SIDE, supra note 80, at 198-99 (reporting that on Sept. 26, 2002, Goldsmith, who was in the Office of DOD General Counsel Haynes, was among several lawyers (including Addington, Gonzales, and Haynes) who flew to Guantanamo to discuss and observe actual use of SERE tactics during interrogations of detainees held in secret detention or forced disappearance). Thus, Goldsmith must have known by 2004 what transfer to "facilitate interrogation" meant under the Bush program both in terms of likely tactics to be used by U.S. and foreign interrogators (especially after having worked for Haynes in the DOD "as 
Valparaiso University Law Review, Vol. 43, N0. 4 [2009], Art. 1

and criminal prohibition of the transfer of any non-prisoner of war out of occupied territory under the Geneva Civilian Convention and customary international law. ${ }^{97}$ To "facilitate interrogation," the Goldsmith memo also made the patently erroneous claim that a detainee who was not lawfully in Iraq could be denied protections under Geneva law. ${ }^{98}$

his 'Special Counsel[]" since September of 2002 and admittedly "worrying about the possibility of excessive interrogations" while at the DOJ in 2003)). GOLDSMITH, supra note 89, at 21, 141; cf id. at 29 (stating that he did not know about the CIA's interrogation program before starting at the DOJ in October 2003, but thereafter he did not oppose the use of any tactic or secret detention), 41 (stating that the conclusion in his OLC opinion of October 2003 was personally communicated to Gonzales and Addington, that all Iraqis of any status in occupied Iraq have protections under the Geneva Civilian Convention), 59 (claiming that, under Haynes at the DOD, Goldsmith was viewed "[a]s a . . critic of many aspects of the international human rights movement, [and] was the perfect person for the assignment[]" to oppose use of human rights law and law of war "judicialization"), 172 (claiming that although his 2004 draft opinion "had circulated in March 2004[,]" he never finalized it and "it never became operational[]"). Concerning the September trip to GTMO, see Senate ASC Report, supra note 76, at xvi.

97 GC, supra note 27, at arts. 49, 147; PAUST, BE YOND THE LAW, supra note 1, at 18, 30, 163-64 nn.147-152. See also Rome Statute of the ICC, supra note 21, at art. 8(2)(a)(vii); Protocol Additional to the Geneva Conventions of 12 August 1949, and Relating to the Protection of Victims of International Armed Conflicts, June 8, 1977, art. 85(4)(a), 1125 U.N.T.S. 3. The rights, duties, and prohibitions reflected in the 1949 Geneva Conventions are "customary international law[.]" See, e.g., PAUST, BEYOND THE LAW, supra note 1, at 8, $134 \mathrm{n} .8$. It is widely known that any violation of the laws of war is a war crime. Id. at 133 n.2. A memorandum by Bybee to Haynes in 2002 also addressed the transfer of members of the Taliban, al Qaeda, and others "who have come under the control of the United States armed forces, to other countries." The memo argued that such transfers were permissible under GPW and (in error) the CAT, but did not address the Geneva Civilian Convention's absolute prohibition of transfer of anyone who is not a prisoner of war. See Jay S. Bybee, Memorandum for William J. Haynes, II, General Counsel, Department of Defense, Re: The President's power as Commander in Chief to transfer captured terrorists to the control and custody of foreign nations (March 13, 2002), available at http://www.usdoj.gov/opa/ documents/memorandumpresidentpower03132002.pdf. The memo erroneously claimed that the CAT does not apply outside U.S. territory. Id. at 23-24. But see CAT Comm. Gen. Comm., supra note 1, paras. 7 ("any person ... subject to the de jure or de facto control of a State"), 16 ("where a State party exercises, directly or indirectly, de facto or de jure control over persons"), 19; PAUST, supra note 1, at 173, 187-88, 190, 199-200. Given control over occupied territory, transfer therefrom can fit within words such as "expel, return ... or extradite" within the meaning of Article 3(1) of the CAT. See CAT, supra note 20, art. 3(1). Because U.S. registered aircraft and vessels are the equivalent of U.S. territory under international law, the same should pertain with respect to transfers from a U.S. aircraft or vessel.

98 See PAUST, BEYOND THE LAW, supra note 1, at 18, 163-64 nn.149-152. There are no gaps in protection from torture or cruel, inhuman or degrading treatment and denial of rights to minimum due process because of the status of a detainee. See, e.g., Hamdan v. Rumsfeld, 548 U.S. 557, 629-31 \& n.63 (2006). PAUST, BEYOND THE LAW, supra note 1, at 1-4, 8, 42, 70, 138 n.20, 183-88, 189-90 n.59, 215 n.27, 267 n.15, 294 n.171. In particular, rights, duties and prohibitions reflected in common Article 3 of the Geneva Conventions are customary international law applicable in all armed conflicts. Hamdan, 548 U.S. at 631 n.63; PAUST, 
In 2005, a memo penned by Steven G. Bradbury of the Office of Legal Counsel at the Department of Justice and approved by then Attorney General Alberto Gonzales provided "an expansive endorsement of the harshest interrogation techniques ever used by the Central Intelligence Agency[,]" including water-boarding and use of "frigid temperatures." 99 In July, 2006, soon after the Supreme Court ruled that detainees are entitled, at a minimum, to the rights reflected in Common Article 3 of the Geneva Conventions, ${ }^{100}$ President Bush signed a new executive order reauthorizing unlawful interrogation tactics such as water-boarding and the "cold-cell" while furthering his program of coercive interrogation and secret detention. ${ }^{101}$ In September 2006, President Bush admitted that a CIA program had been implemented using secret detention and "tough" forms of treatment and that the program would continue. ${ }^{102}$

Later in 2006, Congress enacted the Military Commission Act (MCA), ${ }^{103}$ thereby amending the War Crimes Act. ${ }^{104}$ The MCA was enacted to further define "torture" prohibited under Common Article 3 of the 1949 Geneva Conventions - a violation of which is a war crime under international law, the War Crimes Act, 105 and other federal legislation that was not amended and incorporates all of the laws of war as offenses against the laws of the United States. ${ }^{106}$ However, the MCA's definition does not comply with Article 1 of the CAT, for the following reasons: (1) the MCA definition applies only to torture of a person in the perpetrator's custody or control, whereas the CAT's definition applies to any "complicity or participation in torture[]" of any person; (2) the MCA definition has a limitation with respect to the purposes for which torture

BEYOND THE LAW, supra note 1, at 2-3, 136-38 nn.17, 19.

99 Shane, Johnston \& Risen, supra note 76, at 1 . See also Senate ASC Report, supra note 76, at xvi (Bradbury testified "that the CIA's use of waterboarding was 'adapted from the SERE training program.'”); House Comm. Report, supra note 79, at 134 (on Feb. 14, 2008, "Bradbury provided detailed information about ... the U.S. form of waterboarding").

100 See Hamdan, 548 U.S. at 633, n.63.

101 Shane, Johnson \& Risen, supra note 76 (adding that Bradbury had "reviewed and approved" the 2006 executive order). Bush re-authorized unlawful tactics after their general outlawry the year before in the Detainee Treatment Act, Title $X$ of the Department of Defense Appropriations Act, Pub. L. No. 109-48, § 1003(a) 119 Stat. 2680 (2005). Id. (“No individual in the custody or under the physical control of the United States Government, regardless of nationality or physical location, shall be subject to cruel, inhuman, or degrading treatment or punishment.") (codified at 42 U.S.C. § 2000dd(a)).

102 See, e.g., PAUST, BEYOND THE LAW, supra note 1, at 29.

103 MCA, supra note 58.

10418 U.S.C. § 2441 (2006).

$105 I d$. at $\S 2441(\mathrm{c})(3)$.

10610 U.S.C. $\$ 818$ (2006). See PAUST, BASSIOUNI, ET AL., supra note 26, at 253-59; Jordan J. Paust, After My Lai: The Case for War Crime Jurisdiction Over Civilians in Federal District Courts, 50 TEX. L. REV. 6, 12, at nn.25-26, 11, at n.17, 22, 27, 33 (1971). 
is used, whereas the CAT assures that torture for any purpose is illegal and lists purposes in a non-exclusive manner (i.e., listing purposes with the phrase "such as"); and (3) the definition of "severe mental pain or suffering" in the MCA is limited to the meaning set forth in other U.S. legislation that the Committee Against Torture has already found to be in breach of the Convention's obligation to enact appropriate laws to cover all forms of torture as well as all forms of cruel, inhuman, and degrading treatment. ${ }^{107}$

It is time for new legislation regarding torture and cruel, inhuman and degrading treatment to reach all forms of such unlawful treatment in order to comply with the CAT, human rights law (customary and treatybased), the laws of war (customary and treaty-based), and, more generally, to comply with what the United Nations Security Council and General Assembly have recognized as the duty of all states to end any form of impunity for and to prosecute international crime.108 Full

107 See CAT Report, supra note 22, at $₫ 13$ :

sections 2340 and 2340 A of [title 18 of] the United States Code limit federal criminal jurisdiction over acts of torture to extraterritorial cases. The Committee also regrets that, despite the occurrence of cases of extraterritorial torture of detainees, no prosecutions have been initiated under the extraterritorial torture statute.... [The U.S.] should enact a federal crime of torture consistent with article 1 of the Convention... to prevent and eliminate acts of torture... in all its forms.... [The U.S.] should ensure that acts of psychological torture ... are not limited to 'prolonged mental harm' as set out in the State party's understandings lodged at the time of ratification of the Convention, but constitute a wider category of acts, which cause severe mental suffering, irrespective of their prolongation or its

Id. duration.

The Convention Against Torture mandates that all parties "shall ensure that all acts of torture are offences under its criminal law[]" and "[t]he same shall apply ... to an act by any person which constitutes complicity or participation in torture[]" and, therefore, whether or not such person has custody or control over the victim. CAT, supra note 20, at art. 4(1). See also id. art. 1(1) (the crime reaches conduct "inflicted by or at the instigation of or with the consent or acquiescence of" certain persons, thereby demonstrating that such persons need not have custody or control of victims). The MCA does not "provide immunity from prosecution for any criminal offense[.]" MCA, supra note 58, at §8(b); PAUST, BEYOND THE LAW, supra note 1, at 261 n.115.

108 See, e.g., supra notes 15-16, 26, 37 and accompanying text. President Obama's Executive Order on January 22, 2009 requiring that all U.S. interrogation practices comply, at a minimum, with the requirements under treaty-based and customary international law reflected in common Article 3 of the Geneva Conventions (and, therefore, that all persons "shall in all circumstances be treated humanely") and shall comply with the U.S. Army's interrogation manual is helpful, but does not lessen the need for new legislation to cover all forms of participation in torture and cruel, inhuman, and degrading treatment. See Exec. Order No. 13, 491, 74 Fed. Reg. 4894 (Jan. 22, 2009), available at http://www.whitehouse. 
coverage would also allow the United States to exercise a greater flexibility to request extradition of U.S. and foreign nationals for prosecution in the United States. Otherwise, U.S. extradition requests for the return of U.S. nationals and for the custody of foreign nationals can be denied because of a lack of dual criminality where an alleged offense is not a crime prosecutable under the laws of the foreign country as the requested state and the U.S. as the requesting state. ${ }^{109}$ In such a circumstance, U.S. nationals will be prosecuted in foreign courts using foreign procedures ${ }^{110}$ or rendered to the International Criminal Court ("ICC"). ${ }^{111}$ Moreover, the principle of complementarity set forth in

gov/the_press_office/EnsuringLawfulInterrogations. The U.S. Army manual declares that handling and treatment "must be accomplished in accordance with applicable law and policy," which include "U.S. law; the law of war; relevant international law; [and] relevant directives." U.S. DEP'T OF ARMY,, FIELD MANUAL No. 2-22.3, HuMAN INTELLIGENCE COLLECTOR OPERATIONS vii (Sept. 6 2006), available at http://www.army.mil/references/ FM2-22.3.pdf. Common Article 3 of the Geneva Conventions provides a minimum standard of treatment. Id.; PAUST, BEYOND THE LAW, supra note 1, at 43 . The manual also lists specific tactics that must not be used, such as water-boarding, use of extreme cold, use of dogs, and stripping persons naked and hooding. See PAUST, BEYOND THE LAW, supra note 1, at 43. Of further interest is the fact that the Executive Order's requirement of humane treatment refers to common Article 3 "as a [m]inimum [b]aseline[,]" but notes that treatment must also be consistent with the requirements of the CAT (which also applies in times of relative peace) "and other laws regulating the treatment and interrogation of individuals detained in any armed conflict," among others. See Exec. Order No. 13,491, 74 Fed. Reg. 4894 at Section 3(a).

109 Concerning the customary dual criminality principle, see, e.g., PAUST, BASSIOUNI, ET AL., supra note 26 , at $142,331-32,334,348,351,353-56,377$. If a U.S. amnesty or immunity precludes U.S. prosecution, the U.S. must either extradite or render to an international tribunal. See also supra note 39. One of the worst responses would involve creation of a farcical "truth commission" where lawyered-up Bush Administration officials who are reasonably accused would be granted immunity to testify, but would refuse to testify about secreted meetings, authorizations, findings, directives, and memoranda that the Obama Administration had still not made public despite claims to transparency. If the U.S. could not prosecute such persons, the U.S. obligation would shift to a duty to extradite. Additionally, the U.S. could not assure extradition of such persons from any foreign country exercising universal jurisdiction and they could be prosecuted in any country they visited or in which they were otherwise found. They would have no jury trial and, if found guilty of authorizing or facilitating crime or dereliction of duty, they would most likely serve their sentence in a foreign jail. As Professor Tony D'Amato remarked, they would "lose the home court advantage." Anthony D'Amato, private email to the author.

110 In case of foreign prosecution of U.S. nationals, customary human rights law reflected in Article 14 of the ICCPR provides a set of minimum due process guarantees. See, e.g., Hamdan, 548 U.S. at 633 n.66 (2006); PAUST, BASSIOUNI, ET AL., supra note 26, at 473-74; PAUST, BEYOND THE LAW, supra note 1, at 105, 113, 126-27.

111 Concerning possible ICC jurisdiction over U.S. nationals, see, e.g., Rome Statute of the ICC, supra note 21, at arts. 12(2)(a), 13(a) and (c); Jordan J. Paust, The Reach of ICC Jurisdiction Over Non-Signatory Nationals, 33 VAND. J. TRANSNAT'L L. 1, 5-8, 14-15 (2000). One circumstance that makes ICC jurisdiction possible is where an alleged crime occurs on the territory of a party to the treaty and that party or any other party renders an accused to 
Article 17 of the Statute of the ICC, which requires suspension of ICC prosecution when the United States is able to and "genuinely" proceeds with prosecution in good faith, 112 will not be applicable where U.S. legislation does not cover crimes within the jurisdiction of the ICC or for any other reason the U.S. cannot or will not initiate prosecution of those who are reasonably accused. One set of federal statutes allows prosecution of any war crime in the federal district courts, 113 but presently there is no federal legislation allowing prosecution of crimes against humanity as such. Nonetheless, some crimes against humanity committed during an armed conflict, such as torture and secret detention or forced disappearance of individuals, are also war crimes and can be prosecuted as war crimes. ${ }^{114}$

It is also time for the United States to withdraw its attempted reservation to the CAT which had declared erroneously that the U.S.

considers itself bound by the obligation under Article 16 to prevent 'cruel, inhuman or degrading treatment or punishment,' only insofar as the term 'cruel, inhuman or degrading treatment or punishment' means the cruel, unusual and inhumane treatment or punishment prohibited by the Fifth, Eighth, and/or Fourteenth Amendments to the Constitution of the United States. ${ }^{115}$

\footnotetext{
the Court. Id. at art. 12(2)(a) (ICC jurisdiction exists if " $\mathrm{t}]$ he State on the territory of which the conduct in question occurred" is a party). By the end of 2008, there were 108 parties to the treaty, including Afghanistan. There are no rulings by the ICC yet on point, but it is otherwise normal under customary international law concerning jurisdiction to recognize that when an alleged perpetrator outside the territory of a state (e.g., in Washington, D.C.) intends to produce effects within such state (e.g., Afghanistan) and the relevant conduct occurs within such state by a co-conspirator, an actual agent, or an unknowing or innocent "agent" (a mere "agent" by fiction), that the conduct of the latter person is attributed to the alleged perpetrator just as if the alleged perpetrator engaged in conduct within such state. See, e.g., PAUST, VAN DYKE \& MALONE, supra note 4, at 515-16, 518, 541-42, and cases cited; PAUST, BASSIOUNI, ET AL., supra note 26, at 179-83, and cases cited.

112 See Rome Statute of the ICC, supra note 21 , at art. 17. There is some ambiguity regarding whether a non-party to the treaty can take advantage of Article 17's limitation, but Article 17 might be construed as a limitation of ICC jurisdiction regardless of whether the state that is able to and genuinely does proceed with prosecution of an offense within the treaty is a non-party. Furthermore, since nationals of a non-party can be prosecuted before the ICC under certain circumstances, perhaps the individual accused would have standing to raise Article 17.

113 See supra notes 103-06 and accompanying text.

114 See, e.g., PAUST, BEYOND THE LAW, supra note 1, at 39-40; supra notes 16-17, 21 and accompanying text.

115 Reservation No. 1, available at 136 CONG. REC. S17486-01 (daily ed. Oct. 27, 1990).
} 
The Committee Against Torture under the auspices of the CAT has recognized that, if operative, the putative reservation (which technically is phrased merely as a unilateral understanding that happens to be in plain error and could be withdrawn) would result in a failure to cover all violations of the Convention and that, therefore, the attempted reservation is "in violation of the Convention[.]"116 As in the case of any attempted reservation that is inconsistent with the object and purpose of a treaty, the attempted reservation is void ab initio as a matter of law and has no legal effect. ${ }^{117}$ Thus, it cannot protect the United States or any U.S. national but, as is the case with other void attempted reservations to human rights treaties, it communicates a lack of meaningful commitment to human rights. President Obama can act now to notify the SecretaryGeneral of the United Nations (as the depository for the treaty) that the United States formally withdraws its attempted reservation because it is void as a matter of law. Such an act by the President would help to end an embarrassment for the United States and restore U.S. integrity and respect as a country committed to human dignity and human rights. Concomitantly, President Obama can notify the Secretary-General of the U.S. withdrawal of the same type of putative, but void, reservation to the International Covenant on Civil and Political Rights. ${ }^{118}$

116 See, e.g., PAUST, BEYOND THE LAW, supra note 1, BEYOND THE LAW, at 189-91 n.59 (also addressing a U.N. Experts' Report that agreed with the decision of the CAT Committee). The attempted limitation or false understanding is also incompatible with customary, jus cogens, and U.N. Charter obligations regarding cruel, inhuman, and degrading treatment that pertain in any event. See supra text accompanying notes 3-6.

117 See PAUST, supra note 1, at 143-44 n.43, 189-90 n.59; See Nowak, supra note 69, at 836; PAUST, BEYOND THE LAW, supra note 1, at 143-44 n.43, 189-91 n.59. An attempted declaration of non-self-execution of Articles 1-16 is also inconsistent with the object and purpose of the CAT, since several of the articles are phrased in mandatory "shall" language that is typically self-executing. The declaration should also be withdrawn.

118 See Reservation No. 3, available at 138 CONG. REC. S4781-01 (daily ed. April 2, 1992); Nowak, supra note 69, at 836; PAUST, BEYOND THE LAW, supra note 1, at 143 n.42, 189-91 n.59 (also addressing a U.N. Experts' Report agreeing with the conclusion of the Human Rights Committee that operates under the auspices of the ICCPR that the attempted reservation is inconsistent with the object and purpose of the treaty and is void ab initio as a matter of law). While doing so, President Obama can also withdraw the declaration of partial non-self-execution from the U.S. instrument of ratification regarding the ICCPR because it is also disingenuous and void $a b$ initio as a matter of law. See, e.g., PAUST, INTERNATIONAL LAW AS LAW OF THE UNITED STATES, supra note 26, at 363-66, 368, 376-78 (quoting H.R. Comm., General Comment No. 24, U.N. Doc. CCPR/C/21/REV.1/Add.6 (2 Nov. 1994)). Some do not understand that it was only an attempted declaration of partial non-self-execution and never reached Article 50 of the ICCPR which mandates in clear selfexecuting language that all of " $\mathrm{t}]$ he provisions of the present Covenant shall extend to all parts of federal States without any limitations or exceptions." ICCPR, supra note 33, at art. 50. See PAUST, VAN DYKe \& MALONE, supra note 4, at 87-89, 507-08; PAUST, INTERNATIONAL LAW AS LAW OF THE UNITED STATES, supra note 26, at 361-62. In any event, we cannot lead 


\section{CONCLUSION}

It is time for real change in America. It is time to restore the rule of law; to bring an end to seven years of impunity that must be effectuated through Executive prosecution or extradition of all who are reasonably accused; and to restore American honor, integrity, and respect within the international community. ${ }^{119}$ At this defining moment in our history, none of these critically needed outcomes can be accomplished by new commission or committee reports. ${ }^{120}$ Ultimately, they can only be

in human rights if some of our own rights are held in chains.

119 Concerning various damaging consequences of the Bush Administration's program of serial and cascading criminality, see, e.g., Jordan J. Paust, Serial War Crimes in Response to Terrorism Can Pose Threats to National Security, 35 WM. MITCHELL L. REV. (forthcoming 2009) (addressing the placing of our people in harm's way, mission failure, aid to the enemy, and deflation of authority, our values, law and power, among other consequences). If for any reason the United States fails to prosecute or extradite those who are reasonably accused, the U.S. would remain in violation of critically important treaties and various damaging consequences will continue. Among several abnegative consequences would be a general deflation of respect for the rule of law (especially the laws of war) and doubt within the community whether the United States will fulfill its commitments under other treaties that are of great significance to the international community.

120 New investigations should not be used to postpone prosecution or extradition of those who are already reasonably accused. At most, they would delay the need for President Obama to exercise his constitutionally-based duty to prosecute or extradite those who are later identified as persons reasonably accused of international crime. Presently, there is extensive evidence of manifest criminality engaged in by several individuals and many authoritative reports, published paper trails, and admissions already exist. See, e.g., PAUST, BEYOND THE LAW, supra note 1, at 5-20, 25-30, 32, 35-36, 45-46; supra notes 19, 21-22, 73, 76-80, 107 and accompanying text. They offer proof that what we saw in Abu Ghraib photos and water-boarding, the cold cell, stripping persons naked and use of snarling dogs to instill intense fear are torture authorized and abetted at the highest levels. If they were not torture, they are cruel treatment. If they were not, they constitute inhumane treatment. As such, they are manifest violations of the laws of war and any violation of the laws of war is a war crime. It is time to move beyond what for some has been convenient disbelief and for others has been racist indifference.

A great President must surely realize that we cannot restore the rule of law, we cannot adequately train soldiers to obey the laws of war, we cannot properly move forward without complying with international law and ending impunity through Executive prosecution or extradition of those who are reasonably accused. We must reaffirm the fundamental expectations of the Founders and Framers and countless others here and abroad that no one is above the law - that law exists not merely for those who are outside of government and without substantial wealth or power. See PAUST, BEYOND THE LAW, supra note 1, at xi-xii, 20-23, 65-67, 71-76, 80-81, 86-91, 99; Jordan J. Paust, In Their Own Words: Affirmations of the Founders, Framers, and Early Judiciary Concerning the Binding Nature of the Customary Law of Nations, 14 U.C.DAVIS J. INT'L L. \& POL'Y 205, 205, Et seq. (2008). Former President Bush and others in his Administration have created a major crisis here and abroad with respect to our commitment to the rule of law and consequences for the integrity of government that would only be exacerbated if President Obama does not reaffirm that public servants are bound by the law and, whether or not it is comfortable, 
accomplished by adherence to the express and unavoidable constitutional duty of the President of the United States faithfully to execute the laws, ${ }^{121}$ including customary and treaty-based international law that requires prosecution or extradition of those who authorized, ordered, abetted, or engaged in torture and other forms of illegal treatment of human beings. Never in the long history of the United States has there been such widespread serial criminality authorized and abetted at the highest levels of our government. Never in the history of our country has any other President been known to have authorized war crimes and crimes against humanity.

that he will faithfully execute the laws of the United States, which include treaty-based and customary international legal duties to either initiate prosecution or extradite. It has been left to President Obama to make the decision to end the seven-year trajectory of impunity. It is not a decision for committees, politics, and compromises, but of law.

121 U.S. Const., art. II, $\$ 3$ ("[H]e shall take Care that the Laws be faithfully executed[.]"). For support that such laws include treaties and customary international law and the President is bound thereby, see, e.g., PAUST, supra note 26, at 169-73, and numerous cases cited; PAUST, BEYOND THE LAW, supra note 1 , at 20-23, 72-75, 86, 87-89, 92, 124-25, 168-72 nn.179-195, 233-37 nn.3-5, 20. Every relevant judicial opinion since the beginning of the United States has recognized that the President and all within the Executive branch are bound by the laws of war, a point famously recognized by President Lincoln's Attorney General in 1865 while addressing the need to prosecute war crimes and the lack of congressional power to limit the reach of the laws of war. See, e.g., Op. Att'y Gen. 297, 298300, 307-08 (1865); PAUST, BEYOND THE LAW, supra note 1, at 234-36 n.4; 11. International laws that President Obama must faithfully execute at the beginning of the creation of his legacy include the unavoidable obligation to initiate prosecution of or to extradite all persons of any status who are reasonably accused of war crimes, crimes against humanity, and crimes under the CAT. See, e.g., supra notes $26,28,31$ and accompanying text. 